\title{
Resistensi Hubungan Luar Negeri Amerika Serikat dan Iran: Studi Kasus Joint Comprehensive Plan of Action (JCPOA)
}

\author{
Wildan Ilmanuarif Shafar', Dian Mutmainab² \\ Universitas Brawijaya
}

\begin{abstract}
Since 2015 the United States has been a signatory of the historic nuclear agreement with Iran known formally as the Joint Comprehensive Plan of Action (JCPOA), which was also agreed by other P5+1 countries. JCPOA is the achievement of the U.S. and other P5+1 countries' negotiations with Iran regarding the limitation of Iran's nuclear program. JCPOA is also known to be the vital instrument to reduce Iran's capabilities regarding its aggressive behavior and malign activities, creating destabilization in the Middle East. However, in 2018 the United States government decided to withdraw its participation from the JCPOA. As we know, this decision had an impact on Iran's behavior, which several times violated the contents of the JCPOA agreement even though they did not leave the agreement. We are also witnessing the impact of this decision increase the conflict between the US and Iran in recent years. This research aims to explain the rationale of the U.S. decision to withdraw from the JCPOA nuclear agreement with Iran in 2018. This research using the foreign policy decision-making framework model by Charles W. Kegley and Gregory A. Raymond. This concept focuses on explaining factors of foreign policy decision-making in three sources of analysis and the process of foreign policy-making based on rational choice.
\end{abstract}

Keywords: US Foreign Policy, Iran Nuclear Deal, Foreign Policy Decision Making

\section{PENDAHULUAN}

Pemilihan presiden Amerika Serikat tahun 2020 membawa perubahan kepemimpinan bagi White House. Kekuasaan yang semula berada pada pihak Partai Republik dengan kepemimpinan Trump sebagai presiden ke-45 Amerika Serikat berganti ke pihak Partai Demokrat yang berhasil memenangkan Joe Biden sebagai suksesor Trump. Pergantian pemerintahan Amerika Serikat ini tentu memunculkan implikasi terhadap kebijakan luar negeri 'Paman Sam' pada isu-isu internasional. Tidak terkecuali, kebijakan luar negeri Amerika Serikat terhadap Iran terutama terkait dengan perjanjian nuklir Joint Comprehensive Plan of Action (JCPOA). Perjanjian ini juga dikenal dengan istilah Iran nuclear deal atau perjanjian nuklir Iran.

JCPOA adalah sebuah perjanjian antara Iran yang dianggap telah mengembangkan nuklir hingga tahap yang dikhawatirkan dapat menciptakan senjata nuklir, dengan kelompok negara P5+1 yaitu Amerika Serikat, China, Rusia, Perancis, Inggris, dan Jerman. Secara lebih rinci, perjanjian JCPOA mengharuskan Iran mengurangi dan membatasi pengayaan nuklirnya sebesar dua pertiga dari total kapabilitas nuklirnya dan melakukan pemberhentian fasilitas pengayaan uraniumnya hingga tahun 2030 (Vakil \& Quilliam, 2019). Sebagai ganti dari pengurangan dan pembatasan program nuklir tersebut, sanksi-sanksi terkait program nuklir Iran oleh negara-negara kelompok P5+1 dan beberapa sanksi internasional lainnya akan dicabut (Davenport, 2021). Oleh karena itu, kesepakatan yang menempuh negosiasi panjang mulai dari tahun 2012 hingga 2015 ini mampu membuat Iran bersepakat.

JCPOA atau biasa disebut dengan perjanjian nuklir Iran dianggap sebagai perjanjian bersejarah. Hal ini dikarenakan proses panjang yang dilalui oleh Amerika Serikat dan Eropa. 
Perlu diketahui bahwa negosiasi dengan Iran untuk menghentikan proliferasi nuklirnya telah dilakukan trio negara eropa atau E3 yaitu Jerman, Inggris, dan Perancis sejak tahun 2003 (Cornberg, 2017). Disisi lain, Amerika Serikat berupaya menghentikan proliferasi nuklir Iran melalui pemberian sejumlah sanksi baik secara unilateral atau multilateral sejak tahun 1996 (Katzman, 2021). Upaya internasional untuk meredam program nuklir Iran mencapai puncaknya pada 14 Juli 2015, dimana kelompok negara P5+1 dan Iran akhirnya menyepakati perjanjian JCPOA.

Amerika Serikat yang pada masa itu dipimpin oleh presiden Barack Obama kemudian mengadopsi perjanjian JCPOA melalui Presidential Memoranda yang diterbitkan 18 Oktober 2015 (The White House of President Barack Obama, 2015). Sejak saat itu, Amerika Serikat mulai mencabut beberapa sanksi berkaitan dengan nuklir Iran. Hal tersebut tidak berlangsung lama, pasalnya presiden penggantinya yaitu Donald Trump yang mulai menjabat tahun 2016 di kemudian hari memutuskan Amerika Serikat keluar dari perjanjian JCPOA. Tepatnya pada tanggal 8 Mei 2018, Donald Trump menerbitkan National Security Presidential Memorandum 11 yang secara resmi mengeluarkan Amerika Serikat dari perjanjian tersebut. Tidak hanya itu, Amerika Serikat pun mengembalikan lagi sanksi-sanksi yang pernah berlaku terhadap Iran (Federation of American Scientists, 2018).

Pemerintahan Donald Trump menganggap bahwa perjanjian JCPOA tidak cukup baik untuk membatasi Iran agar tidak memiliki senjata nuklir. Perjanjian tersebut juga dinilai tidak bisa meredam pengaruh Iran yang mengancam stabilitas keamanan di Timur Tengah (Beauchamp, 2018). Keputusan Amerika Serikat ini menarik untuk dianalisis, pasalnya perjanjian JCPOA adalah kesepakatan penting untuk menjaga stabilitas keamanan dunia terutama untuk menghindari ancaman proliferasi senjata nuklir. Dennis Jett menyatakan bahwa tujuan JCPOA adalah untuk memberikan jaminan kepada dunia bahwa program nuklir Iran tidak akan digunakan untuk membuat senjata nuklir (Jett, 2018). Sebuah perjanjian yang ditujukan untuk menciptakan stabilitas keamanan khususnya di kawasan Timur Tengah sekaligus Dunia.

Senada dengan Dennis Jett, Ernest J. Moniz dalam pernyataan pers di laman web Harvard.edu menjelaskan bahwa perjanjian JCPOA pada intinya adalah tentang menghilangkan kemampuan Iran untuk memiliki bahan utama nuklir yaitu uranium dan plutonium. Bahan ini diproses dengan metode enrichment untuk digunakan sebagai bahan utama dalam membuat senjata nuklir. Perjanjian tersebut menjadi sangat penting untuk mengurangi kapabilitas Iran dalam perilakunya yang cenderung agresif melakukan destabilisasi keamanan di kawasan Timur Tengah. Moniz mengungkapkan bahwa keputusan keluar dari JCPOA merupakan kesalahan strategis yang dilakukan Amerika Serikat. Keluarnya Amerika Serikat dari perjanjian tersebut justru membuat AS kehilangan kesempatan untuk mengendalikan Iran agar tidak dapat memperoleh kapabilitas pembuatan senjata nuklir (The Harvard Gazette, 2018).

Para ahli memprediksi bahwa keputusan tersebut akan berdampak buruk bagi upaya menjaga keamanan dunia dari ancaman proliferasi nuklir Iran. Karim Sadjadpour menyatakan bahwa keputusan tersebut dapat meng-eskalasi konflik militer antara Iran dan Amerika Serikat, atau Iran dan Israel (Sanger, 2017). Ia juga berpendapat bahwa Iran akan mulai kembali melaksanakan ambisi nuklirnya meski bukan dalam skala sebesar sebelum adanya perjanjian JCPOA (Chotiner, 2018). Menurutnya, hal ini adalah konsekuensi yang tidak bisa dihindari karena Iran tentu akan menganggap AS telah mengingkari kesepakatan dan komitmen dalam perjanjian tersebut. Belakangan ini, kedua prediksinya tersebut kemudian terbukti menjadi kenyataan. Konfrontasi militer menggunakan drone oleh Amerika Serikat terhadap militer Iran berakibat pada tewasnya salah satu jenderal militer Iran yaitu Qasem Soleimani pada 3 Januari 2020 lalu (Rasheed, 2020). 
Sementara itu, John Kerry menyatakan bahwa keputusan AS keluar dari JCPOA memberikan dampak cukup serius bagi dinamika hubungan AS dan Iran. Menurut Kerry, Amerika Serikat mengabaikan konsekuensi moral bahwa kepercayaan Iran terhadap pemerintahan AS akan menurun dalam hal negosiasi atau perjanjian internasional (Aljazeera, 2018). Hal ini karena Iran sebagaimana telah diverifikasi oleh IAEA telah mematuhi isi perjanjian yang ada (Dixit, 2018). Kondisi ini membuat Iran tidak akan dengan mudah kembali menaruh kepercayaan kepada AS yang secara sepihak keluar dari JCPOA. Pada saat itu, Ia memperingatkan jika AS keluar dari JCPOA maka dalam waktu dekat Iran akan melanggar larangan-larangan yang telah disepakati dalam JCPOA (Morello, 2018). Peringatannya pun menjadi realita, Iran tercatat telah 5 kali melanggar ketentuan perjanjian JCPOA semenjak AS keluar dari perjanjian tersebut (Davenport, 2021).

Dinamika politik domestik AS berubah sejak pemilu pada tahun 2020 yang dimenangkan oleh Joe Biden dari Partai Demokrat. Sebagaimana telah menjadi pengetahuan umum, Partai Demokrat dan Partai Republik memiliki pendirian yang berbeda dalam isu nuklir Iran. Pada Munich Security Conference tahun 2021 ini, presiden Joe Biden menyatakan bahwa Amerika Serikat tengah mempersiapkan diri untuk kembali bergabung bersama kelompok negara P5+1 dan perjanjian JCPOA (The White House, 2021). Langkah yang Ia ambil berdasarkan salah satu janjinya ketika kampanye yang menginginkan AS untuk bergabung kembali dengan perjanjian JCPOA jika Iran kembali mematuhi perjanjian tersebut (Biden, 2020). Dari sini kita dapat melihat, terdapat kecenderungan besar bagi AS yang telah keluar dari JCPOA sejak tahun 2018 untuk kembali bergabung.

Namun untuk mencapai hal tersebut bukan perkara yang mudah karena keputusan AS keluar dari perjanjian nuklir Iran pada tahun 2018 tentu didorong oleh faktor-faktor determinan pengambilan keputusan yang kuat. Oleh karena itu, pembahasan mengenai alasan keluarnya AS dari perjanjian nuklir Iran menjadi penting untuk memahami dinamika keputusan AS. Melalui tulisan ini, penulis ingin meninjau kembali alasan dibalik keputusan AS keluar dari perjanjian Joint Comprehensive Plan of Action (JCPOA) pada tahun 2018. Pertama, penulis akan membahas faktor-faktor determinan yang dapat mempengaruhi keputusan pemerintahan Trump saat itu terhadap perjanjian JCPOA. Kedua, penulis akan membahas proses pengambilan keputusan AS pada masa itu menggunakan konsep rational choice.

\section{KERANGKA PEMIKIRAN}

Keputusan AS keluar dari perjanjian JCPOA telah menjadi perbincangan hangat di dunia internasional. Terdapat beberapa tulisan ilmiah yang menjadi studi terdahulu dalam penelitian ini. Stephen P. Mulligan dalam Withdrawal from the Iran Nuclear Deal: Legal Authorities and Implications membahas mengenai aspek dampak hukum keluarnya AS dari perjanjian JCPOA. Aspek dampak hukum pertama yang dilihat adalah peraturan hukum domestik terkait keputusan AS keluar dari perjanjian JCPOA. Studi terdahulu ini juga melihat pada aspek hukum internasional yang terdampak dari keluarnya AS dari perjanjian JCPOA. Selain itu, studi terdahulu ini juga melihat potensi konflik hukum dari keluarnya AS dari perjanjian JCPOA (Mulligan, 2018).

Studi terdahulu kedua adalah tulisan Dennis C. Jett yang berfokus pada identifikasi pada pengaruh kelompok kepentingan terhadap kebijakan AS dalam isu nuklir Iran. Dalam bukunya, Jett menjelaskan taktik-taktik yang digunakan oleh kelompok-kelompok tersebut untuk mempengaruhi kebijakan AS terhadap perjanjian nuklir Iran. Secara umum, buku ini lebih membahas mengenai pengaruh politik partisan di AS terhadap kebijakan AS dalam isu Iran (Jett, 2018). 


\section{Pengambilan Keputusan dalam Kebijakan Luar Negeri}

Dalam studi mengenai kebijakan luar negeri, terdapat banyak penjelasan mengenai definisi kebijakan luar negeri itu sendiri. K.J. Holsti menyatakan bahwa kebijakan luar negeri merupakan gabungan dari ide-ide yang telah direncanakan oleh pembuat kebijakan dengan tujuan untuk mengurus suatu permasalahan dan merespon perubahan sikap atau kebijakan negara lain (Holsti, 1983). Sedangkan menurut Rosenau, kebijakan luar negeri didefinisikan sebagai suatu orientasi politik negara, sebuah rencana, atau sebuah perilaku negara (Rosenau, Boyd, \& Thompson, 1976). William Wallace mendefinisikan kebijakan luar negeri sebagai pengambilan keputusan yang diambil oleh negara yang ditujukan terhadap lingkungan internasional dan didorong oleh sejumlah sumber yang berbeda (Wallace, 1971).

Pada tulisan ini penulis menggunakan model foreign policy decision making oleh Charles Kegley dan Gregory Raymond. Menurut Kegley dan Raymond, kebijakan luar negeri dan proses pembuatan yang menyertainya adalah tujuan yang negara (aktor non-negara) ingin capai di lingkungan eksternalnya, nilai yang melatarbelakangi tujuan tersebut, dan instrumen yang digunakan untuk mencapai tujuan tersebut. Mereka mengemukakan bahwa terdapat dua hal yang perlu diperhatikan dalam melakukan analisis pembuatan keputusan dalam kebijakan luar negeri. Pertama adalah faktor-faktor determinan dalam pembuatan suatu kebijakan luar negeri dan yang kedua adalah proses pengambilan keputusan berdasarkan pilihan rasional (Kegley \& Raymond, 2009).

Gambar 1. Dinamika Pembuatan Kebijakan Luar Negeri

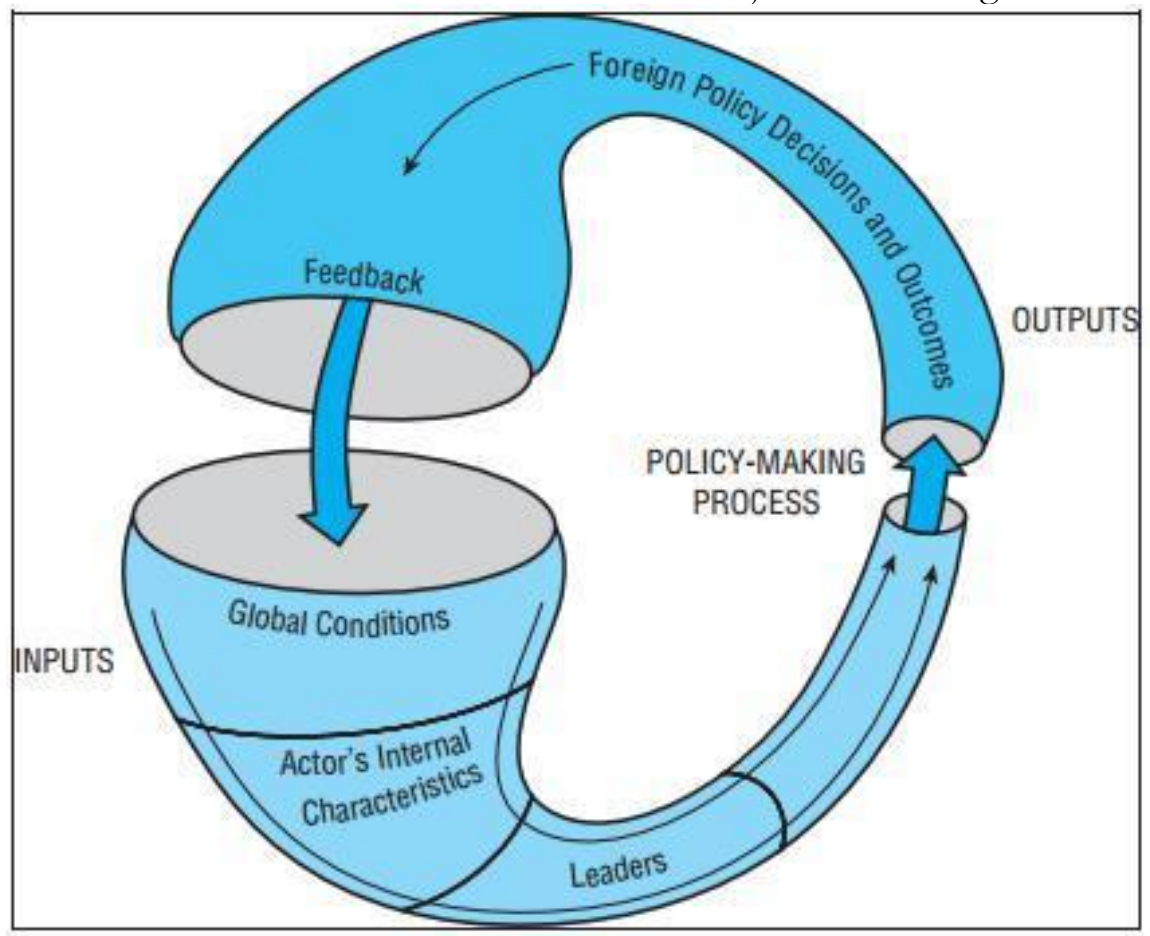

Sumber: Charles William Kegley dan Gregory A. Raymond

Gambar diatas adalah kerangka analisis kebijakan luar negeri yang dikemukakan oleh Kegley dan Raymond dimana suatu kebijakan luar negeri merupakan hasil dari beberapa faktor inputs yang kemudian mempengaruhi proses pembuatan kebijakan luar negeri hingga menghasilkan suatu outputs keputusan kebijakan luar negeri. Kebijakan luar negeri yang diputuskan memunculkan feedback berupa inputs. Dalam hal ini inputs berupa faktor-faktor determinan berupa global conditions (faktor internasional), actor's internal characteristics (faktor 
domestik), dan leaders (faktor individu). Feedback dapat juga diartikan sebagai konsekuensi atau dampak dari suatu keputusan kebijakan luar negeri yang negara ambil pada kesempatan sebelumnya (Blanton \& Kegley, 2011).

Tiga faktor determinan tadi kemudian menjadi pertimbangan negara dalam proses pengambilan keputusan yang merupakan prosedur yang rapi, tertata, dan rasional. Pembuatan keputusan yang rasional ini merujuk pada prosedur pembuatan kebijakan yang melakukan pendefinisian masalah yang muncul secara hati-hati, penentuan secara spesifik tujuan yang ingin dicapai, mempertimbangkan masing-masing alternatif kebijakan yang muncul, dan pemilihan alternatif yang paling optimal untuk mencapai tujuan (Kegley \& Raymond, 2009). Kegley dan William menyebut proses ini sebagai procedural rationality atau dalam studi kebijakan luar negeri sering dikenal dengan istilah rational choice.

Faktor pertama yang menjadi sumber dari pembuatan kebijakan luar negeri adalah faktor internasional. Beberapa hal yang perlu diperhatikan dalam sumber ini adalah polaritas dan polarisasi diantara negara-negara besar dalam sistem internasional dan posisi geostrategis suatu negara. Sumber kedua adalah faktor domestik yang berfokus melihat kapasitas internal yang dimiliki suatu negara untuk melakukan tindakan tertentu yang ditujukan ke lingkungan internasional. Beberapa hal yang harus diperhatikan dalam sumber ini adalah kapabilitas militer dan ekonomi, posisi lembaga pemerintahan, dan opini publik terhadap isu internasional yang dihadapi. Sedangkan faktor ketiga atau sumber individu lebih melihat orientasi kepemimpinan, pandangan pemimpin terhadap negara lain, dan otoritas pemimpin dalam pengambilan keputusan (Kegley \& Raymond, 2009).

Penelitian ini termasuk kedalam jenis penelitian eksplanatif. Menurut Mohtar Mas'oed, eksplanasi adalah upaya untuk menjawab tipe pertanyaan "mengapa". Jenis pertanyaan ini digunakan untuk mengungkapkan alasan atau penyebab sesuatu terjadi (Mas'oed, 1990). Ruang lingkup penelitian ini menjelaskan mengenai faktor-faktor determinan yang menjadi alasan yang memungkinkan terbentuknya keputusan AS keluar dari JCPOA tahun 2018 menggunakan kerangka analisis model pembuatan kebijakan luar negeri yang dikemukakan Kegley dan Raymond. Penulis menggunakan teknik pengumpulan data yang bersifat sekunder atau kepustakaan (library research). Data penulis kumpulkan melalui kegiatan mengumpulkan, mempelajari, dan menganalisis data yang didapatkan dari berbagai sumber seperti buku, jurnal, dokumen-dokumen resmi, artikel, media massa baik yang berbentuk tercetak maupun elektronik serta data dari internet yang menyediakan sumber relevan untuk penelitian penulis.

\section{HASIL DAN PEMBAHASAN}

\section{Aliansi Kelompok Negara P5+1}

Kelompok negara P5+1 merupakan kumpulan negara anggota tetap Dewan Keamanan PBB ditambah Jerman yang bertujuan untuk melakukan upaya negosiasi bersama kepada Iran untuk memperoleh kesepakatan agar negara tersebut dapat menggunakan program nuklirnya untuk keperluan damai (European External Action Service, 2018). Namun, karakteristik kelompok negara $\mathrm{P} 5+1$ hanyalah sebatas sekumpulan negara yang bersama-sama melakukan negosiasi dengan Iran tanpa adanya ikatan aliansi. Satu-satunya hal yang membuat negara-negara dalam kelompok tersebut bersatu adalah karena adanya kesamaan tujuan untuk mencegah Iran memperoleh senjata berbasis nuklir. Hal ini membuat tidak adanya suatu ikatan yang membuat negara dalam kelompok tersebut untuk saling menahan diri untuk menyesuaikan kebijakan luar negerinya terhadap sikap negara lain apabila salah satu negara menghendaki strategi berbeda untuk mencapai tujuan tersebut.

AS dan negara-negara Eropa seperti Jerman, Perancis, dan Inggris sudah diketahui memiliki hubungan yang cukup dekat dalam politik internasional. Dalam konteks perjanjian 
JCPOA, pemimpin negara-negara tersebut dilaporkan menjalin komunikasi kepada pemerintahan Trump terkait wacana pembuatan keputusan AS keluar dari perjanjian tersebut. Presiden Prancis Emmanuel Macron melakukan kunjungan ke AS untuk berdiskusi dengan Presiden AS Donald Trump pada 24 April 2018 (Borger \& Smith, 2018). Pertemuan tersebut ditujukan salah satunya untuk meyakinkan AS tetap berada dalam perjanjian JCPOA. Presiden Perancis tersebut berusaha meredam wacana keputusan AS untuk keluar dari perjanjian JCPOA. Beberapa hari setelah kunjungan tersebut, Kanselir Jerman Angela Merkel pada tanggal 27 April 2018 mendatangi Washington untuk tujuan yang sama (Wilkinson \& Bierman, 2018). Namun, dua kunjungan yang dilakukan kedua negara tersebut tidak menghasilkan sesuatu apapun.

Meskipun hubungan AS dengan Perancis, Inggris, dan Jerman sangat dekat dan bahkan ketiga negara tersebut seringkali disebut sebagai sekutu AS di Eropa, penulis tidak menemukan adanya suatu perjanjian atau komitmen yang mengikat satu sama lain diantara kedua pihak terutama terkait perjanjian JCPOA. Kedekatan kedua pihak dalam konteks perjanjian JCPOA hanya sebatas kunjungan dan rekan diskusi saja karena adanya kesamaan tujuan serta hubungan baik yang telah terbangun sejak lama. AS tidak terikat komitmen apapun terhadap ketiga negara Eropa tersebut untuk menyesuaikan diri dalam pembuatan keputusan.

Menurut Kegley dan Gregory Raymond, ketika negara berada pada lingkungan aliansi yang renggang maka negara tersebut cenderung memiliki ruang gerak lebih untuk membuat keputusan kebijakan luar negeri secara mandiri tanpa mengikuti kehendak negara lain (Kegley \& Raymond, 2009). Dari pembahasan diatas dapat dilihat bahwa AS sebagai bagian dari kelompok negara P5+1 tidak memiliki keterikatan apapun yang membuat AS perlu mengimbangi kehendak negara lain dari kelompok tersebut. Oleh karena itu, maka dapat disimpulkan bahwa karakteristik aliansi AS yang renggang dengan negara-negara dalam perjanjian JCPOA memungkinkan AS untuk membuat keputusan keluar dari perjanjian tersebut.

\section{Strategi Geopolitik Amerika Serikat di Timur Tengah}

Jika melihat konteks geopolitik, letak AS dan Iran yang berjauhan tentu membuat ancaman keamanan bagi negeri 'paman sam' tersebut tidaklah begitu besar. Namun perlu diperhatikan juga bahwa AS memiliki beberapa negara aliansi di timur tengah. Hal ini tentu menjadi pertimbangan AS dalam menentukan kebijakan luar negerinya terhadap Iran. AS secara tradisional berhubungan baik dengan Israel dan Arab Saudi terutama pada sektor keamanan dan ekonomi. AS diketahui telah memberi Israel dukungan diplomatic, ekonomi, dan militer berjumlah lebih dari 115 miliar USD sejak 1949 (Eisenstadt \& Pollock, 2012). Kerjasama keamanan AS-Israel berawal sejak era Perang Dingin yang mana AS melihat Israel sebagai rekan untuk melawan pengaruh Soviet di Timur Tengah. Sampai saat ini, Israel tetap menjadi penyeimbang bagi AS untuk melawan kekuatan radikal seperti terorisme dan ekstremisme di kawasan tersebut (Blackwill \& Gordon, 2016). Dalam konteks nuklir, kerjasama AS-Israel bahkan telah mencegah Irak dan Suriah dari proliferasi senjata nuklir (Eisenstadt \& Pollock, 2012).

Sementara itu hubungan dekat antara AS dan Arab Saudi terbagun atas kerjasama yang saling menguntungkan. Arab Saudi sebagai produsen minyak terbesar di dunia memastikan pasar energy global yang stabil melalui kebijakan energinya dan sebagai gantinya AS hadir dengan memberikan jaminan keamanan terhadap ancaman regional. Pada masa pemerintahan Obama, AS diketahui menandatangani kesepakatan penjualan persenjataan sebesar 700 Miliar USD (Echagüe, 2015). Hal ini menunjukkan betapa eratnya hubungan kedua negara tersebut. Dalam konteks nuklir, AS dan Arab Saudi berbagi kepentingan 
terhadap Iran. AS ingin menghindari proliferasi nuklir agar keamanan negaranya dapat terjaga, mengingat kedua negara memiliki sejarah panjang permusuhan sejak pergantian rezim di Iran dari dinasti Pahlavi ke rezim revolusi islam. Sementara itu, Iran bagi Arab Saudi adalah negara rival dalam hal memperebutkan pengaruh di kawasan Timur Tengah.

Gambar 2. Jangkauan Rudal Iran

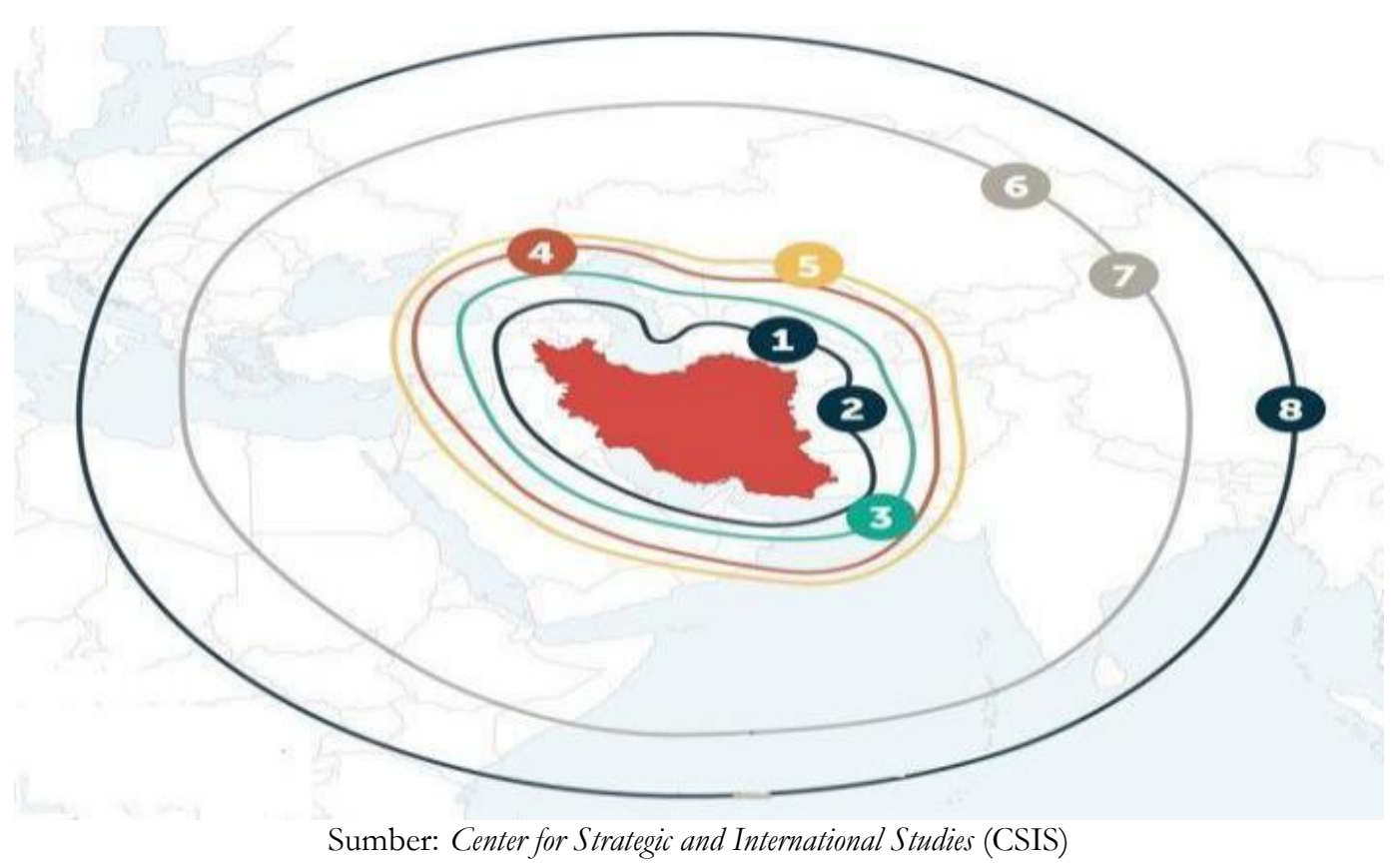

Dalam satu dekade terakhir, Iran telah berkembang pesat dalam teknologi rudal. Menurut laporan CSIS, Iran memiliki persenjataan rudal terbesar dan paling beragam di Timur Tengah. Hal ini membuat Iran menjadi ancaman serius bagi AS dan pasukan militer negara lainnya yang menjadi mitra 'paman sam' di wilayah tersebut. Sebagaimana ditunjukkan pada gambar diatas, rudal Iran dapat menjangkau Israel dan Arab Saudi. Menurut laporan CSIS, kemampuan rudal Iran juga mampu menjangkau sebagain wilayah Eropa dan Asia Tenggara (CSIS Missile Defense Project, 2020). Sejak tahun 2017-2020, Iran tercatat telah meluncurkan serangan rudal sebanyak tujuh kali yang menyasar beberapa wilayah seperti Suriah, Irak, dan Arab Saudi. Serangan ini menargetkan beberapa tempat seperti markas ISIS, fasilitas pengeboran minyak, dan fasilitas militer. Secara geopolitik, hal ini tentu menjadi faktor yang dipertimbangkan AS dalam pengambilan keputusan terkait perjanjian JCPOA.

\section{Kapabilitas Militer dan Ekonomi AS}

Amerika Serikat merupakan negara dengan kekuatan militer peringkat pertama diantara negara-negara lain di seluruh dunia. Kekuatan militer AS ini salah satunya didukung oleh anggaran belanja militer yang tinggi. Negeri Paman Sam tersebut pada tahun 2018 memiliki anggaran belanja militer sebesar 716 Miliar USD dan merupakan yang tertinggi diantara negara-negara lain di dunia (Global Fire Power, 2018). Militer AS juga diperkuat dengan keberadaan pangkalan militer yang tersebar di seluruh dunia. AS memiliki 800 pangkalan militer di lebih dari 70 negara mulai dari pangkalan besar hingga pangkalan yang hanya sebatas fasilitas bagi sistem radar (Vine, 2015). 
Tabel 1. Kapabilitas Militer Negara-Negara Penandatangan JCPOA

\begin{tabular}{|c|c|c|c|c|c|c|c|c|c|}
\hline Negara & $\begin{array}{l}\text { Jumlah } \\
\text { Personil }\end{array}$ & \begin{tabular}{|c} 
Alat \\
Pertahanan \\
Udara
\end{tabular} & \begin{tabular}{|c|} 
Jet \\
Tempur
\end{tabular} & Heli- & Tank & $\begin{array}{c}\text { Kendara- } \\
\text { an Lapis } \\
\text { Baja }\end{array}$ & $\begin{array}{l}\text { Kapal } \\
\text { Induk }\end{array}$ & $\begin{array}{l}\text { Kapal } \\
\text { Selam }\end{array}$ & $\begin{array}{c}\text { Kapal } \\
\text { Destro- } \\
\text { yer }\end{array}$ \\
\hline $\begin{array}{l}\text { Amerika } \\
\text { Serikat }\end{array}$ & 2.083 .100 & 13.362 & 1.962 & 5.758 & 5.884 & 38.882 & 20 & 66 & 65 \\
\hline Iran & 934.000 & 505 & 150 & 145 & 1.650 & 2.215 & 0 & 33 & 0 \\
\hline Tiongkok & 2.693 .000 & 3.035 & 1.125 & 195 & 7.716 & 9000 & 1 & 73 & 29 \\
\hline Rusia & 3.586 .128 & 3.194 & 818 & 1.451 & 20.300 & 27.400 & 1 & 62 & 13 \\
\hline Perancis & 388.635 & 1.262 & 299 & 570 & 406 & 6.330 & 4 & 10 & 12 \\
\hline Inggris & 279.230 & 832 & 103 & 333 & 227 & 5.371 & 2 & 10 & 6 \\
\hline Jerman & 208.641 & 714 & 94 & 384 & 432 & 4.620 & 0 & 6 & 0 \\
\hline
\end{tabular}

Sumber: Diadopsi dari laporan Global Fire Power (Globalfirepower.com, 2018)

Di Timur Tengah, AS juga terhitung memiliki banyak pangkalan militer. Negaranegara yang cukup banyak kehadiran personel militer AS adalah Kuwait, Qatar, Bahrain, Irak, Uni Emirat Arab, Jordania, dan Oman. Jumlah tentara AS di Timur Tengah terbanyak berada di Kuwait tercatat sebesar 15.000 personel, di Qatar sebanyak 10.000 personel dan di Bahrain sebanyak 7.000 personel. Sedangkan di Irak personel militer AS berjumlah 5.165 dan di Uni Emirat Arab sebanyak 5.000 personel. Negara lain seperti Jordania terdapat 1.500 personel militer AS dan Oman tercatat ada 200 personel. Selain di kawasan Timur Tengah, AS juga menempatkan personel militernya dengan angka yang cukup besar di Afghanistan yaitu sebanyak 13.400 personel (McCarthy, 2018).

Gambar 3. Peta Sebaran Pangkalan AS di Timur Tengah

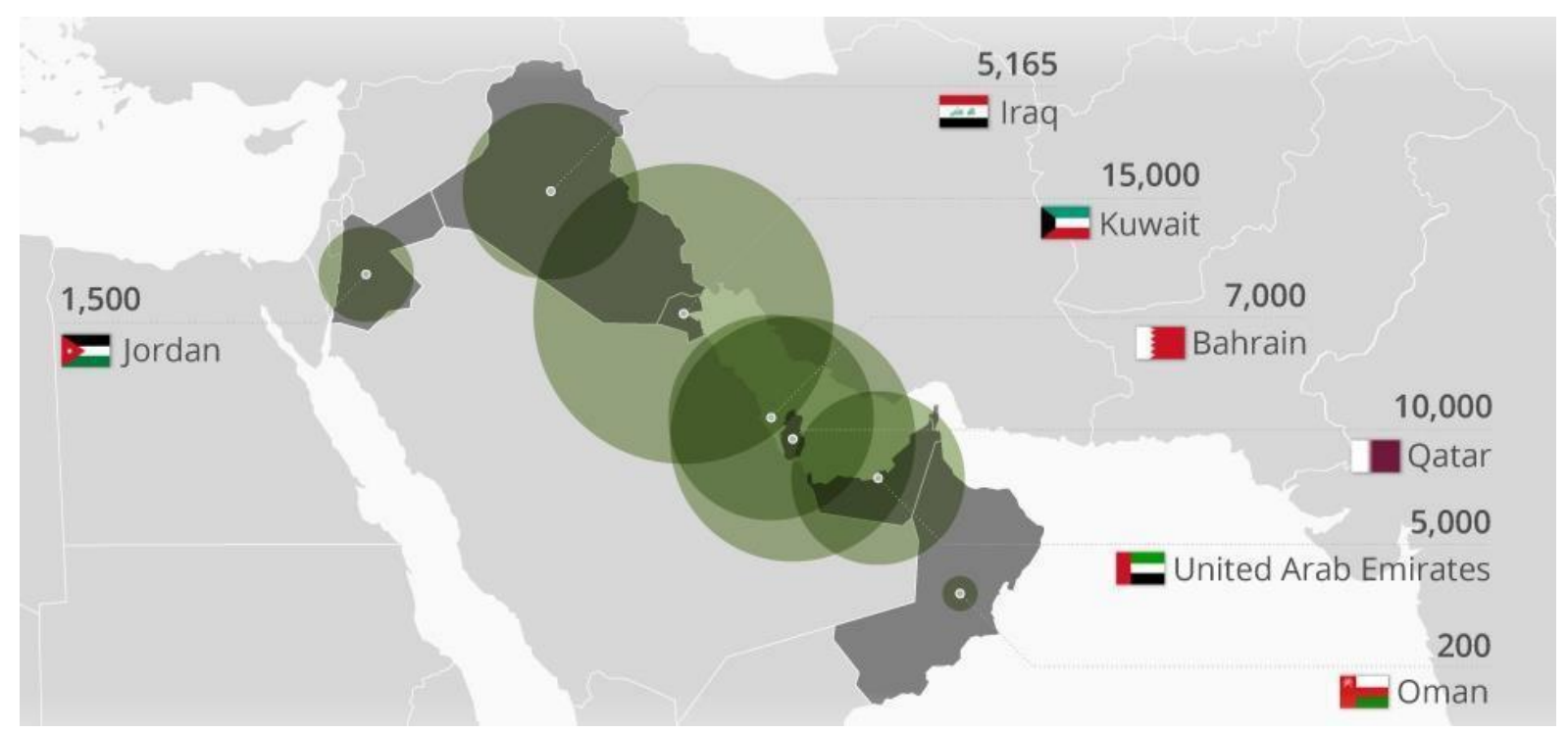

Sumber: Nial McCartby (Statista, 2018) 
Selain keberadaan personel militer yang cukup banyak di kawasan Timur Tengah, AS juga diperkuat dengan kepemilikan hulu ledak nuklir yang cukup melimpah. AS berada di posisi kedua negara pemilik hulu ledak nuklir terbanyak di dunia hanya kalah dari Rusia yang memiliki sebanyak 6.850 hulu ledak nuklir (Radio Free Europe Radio Liberty, 2018). Kedua negara tersebut jika digabungkan tercatat memiliki 92\% dari total keseluruhan hulu ledak nuklir yang ada di dunia. Negeri paman sam tersebut juga tercatat sebagai salah satu dari 5 negara dengan kepemilikan rudal balistik terkuat. Rudal balistik AS bersama dengan Rusia, Tiongkok, Inggris, dan Perancis dilaporkan mempunyai rudal balistik yang mampu menjangkau seluruh bagian dunia (Pecanha \& Collins, 2018).

Gambar 4. Jangkauan Rudal Balistik 5 Negara Terkuat

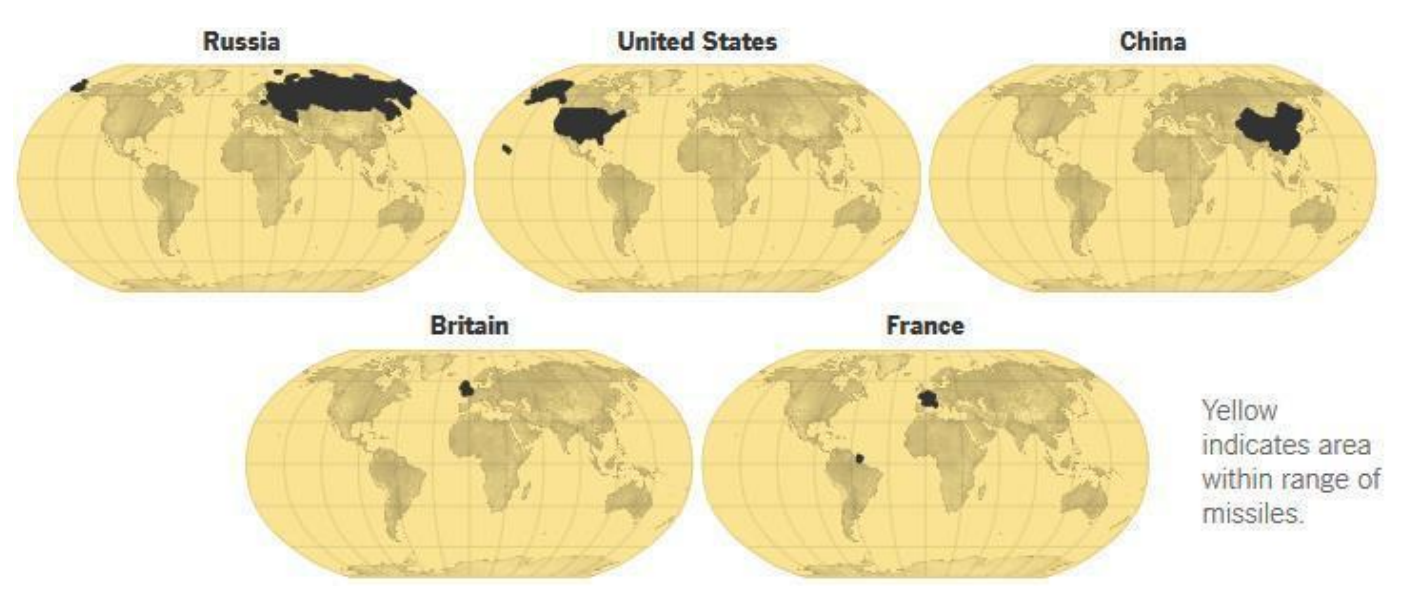

Sumber: Sergio Pecanha dan Keith Collins (New York Times, 2018)

Menurut Kegley dan Raymond, negara dengan kekuatan militer yang besar cenderung melakukan tindakan agresif dan provokatif. Besarnya kekuatan militer suatu negara juga dapat membuat negara tersebut lebih leluasa dalam mengambil keputusan yang dikehendaki (Kegley \& Raymond, 2009). Menurut penulis, AS dengan kapabilitas kekuatan militernya yang sangat kuat dibanding Iran membuat AS lebih berani dalam mengambil keputusan yang beresiko, tidak terkecuali dalam isu JCPOA. Keputusan AS keluar dari JCPOA yang cenderung provokatif dan beresiko tidak menjadi suatu masalah yang berarti bagi AS apabila pada akhirnya keputusan tersebut berujung pada kemungkinan keluarnya Iran dari perjanjian JCPOA dan terciptanya konflik bersenjata dengan Iran.

Tabel 2. Kekuatan Ekonomi Negara-Negara JCPOA

\begin{tabular}{|c|c|c|c|c|c|c|}
\hline Amerika & Tiongkok & Jerman & Inggris & Perancis & Rusia & Iran \\
Serikat & & & & & & \\
\cline { 2 - 7 } Total GDP & Total GDP & Total GDP & Total GDP & Total GDP & Total GDP & Total GDP \\
20,51 & 13,46 & 4,03 & 2,81 & 2,79 & 1,58 & 30,08 \\
Triliun & Triliun & Triliun & Triliun & Triliun & Triliun & Milyar \\
USD & USD & USD & USD & USD & USD & USD \\
& & & & & & \\
Pertumbuhan & Pertumbuhan & Pertumbuhan & Pertumbuhan & Pertumbuhan & Pertumbuhan & Pertumbuhan \\
GDP & GDP & GDP & GDP & GDP & GDP & GDP \\
$2,27 \%$ & $6,9 \%$ & $2,22 \%$ & $1,78 \%$ & $1,82 \%$ & $1,54 \%$ & $3,7 \%$ \\
\hline
\end{tabular}

Sumber: Diadopsi dari laporan World Bank (Worldbank.org, 2017) 
Amerika Serikat merupakan negara dengan kondisi perekonomian yang kuat dengan catatan GDP terbesar di dunia dengan nilai sebesar 20,51 Triliun USD (World Bank, 2017). Perbandingan GDP dan pertumbuhan GDP AS dan negara-negara lain yang menjadi anggota perjanjian JCPOA telah penulis rangkum pada tabel diatas. Tingkat pertumbuhan GDP AS pada tahun 2017 menunjukkan tren positif dengan angka 2,27 persen (World Bank, 2017). Diantara negara-negara dalam perjanjian JCPOA, tingkat pertumbuhan GDP AS berada di urutan ketiga terbesar setelah Tiongkok dan Iran. Meskipun pada tingkat pertumbuhan ekonomi ini AS berada dibawah Tiongkok dan Iran namun kekuatan ekonomi AS masih belum terkalahkan oleh kedua negara tersebut mengingat besarnya jumlah GDP yang dimiliki Amerika Serikat.

Tabel 3. Nilai Perdagangan Negara dalam Perjanjian JCPOA dengan Kawasan Timur Tengah

\begin{tabular}{|l|l|l|}
\hline \multicolumn{1}{|c|}{ Negara } & \multicolumn{1}{|c|}{ Ekspor } & \multicolumn{1}{c|}{ Impor } \\
\hline Tiongkok & 124,58 Miliar USD & 124,58 Miliar USD \\
\hline Amerika Serikat & 73,16 Miliar USD & 75,12 Miliar USD \\
\hline Jerman & 50,81 Miliar USD & 50,81 Miliar USD \\
\hline Perancis & 34,45 Miliar USD & 34,45 Miliar USD \\
\hline Inggris & 29,30 Miliar USD & 29,30 Miliar USD \\
\hline Iran & 9,9 Miliar USD & 9,9 Miliar USD \\
\hline Rusia & 17,11 Miliar USD & 17,11 Miliar USD \\
\hline
\end{tabular}

Sumber: Diadopsi dari laporan World Bank (Worldbank.org, 2017)

Negara-negara kelompok P5+1 juga memiliki nilai perdagangan yang besar ke kawasan Timur Tengah. Pada tahun 2017 ekspor Amerika Serikat ke kawasan tersebut memiliki nilai sebesar 73,16 Miliar USD, sedangkan nilai impornya sebesar 75,12 Miliar USD. Amerika Serikat menempati urutan kedua nilai perdagangan terbesar ke Timur Tengah diantara negara-negara P5+1 lainnya. Urutan pertama ditempati oleh Tiongkok dengan nilai ekspor ke Timur Tengah sebesar 124,58 Miliar USD dan nilai impor sebesar 114,86 Miliar USD.168 Di urutan ketiga ada Jerman dengan nilai ekspor dan impor secara berurutan sebesar 50,81 Miliar USD dan 15,57 Miliar USD.

Lalu urutan keempat ditempati oleh Perancis dengan nilai ekspor ke Timur Tengah sebesar 34,45 Miliar USD, sedangkan nilai impornya sebesar 28,34 Miliar USD.170 Posisi selanjutnya di urutan kelima ada Inggris dengan nilai ekspor ke kawasan tersebut sebesar 29,30 Miliar USD dan nilai impor dari kawasan tersebut ke Inggris sebesar 13,06 Miliar USD.171 Pada urutan keenam ada Iran dengan nilai ekspor di kawasan Timur Tengah sebesar 9,9 Miliar USD dan nilai Impor sebesar 18,8 Miliar USD. Sedangkan di urutan ketujuh adalah Rusia yang memiliki nilai ekspor ke kawasan Timur Tengah sebesar 17,11 Miliar USD dan nilai impor dari kawasan tersebut ke Rusia sebesar 2,85 Miliar USD (World Bank, 2017).

Penjelasan diatas menunjukkan bahwa AS berdasarkan jumlah GDP memiliki tingkat perekonomian yang tinggi dan berada pada peringkat nomor satu di dunia. Bersamaan dengan itu, pertumbuhan ekonomi AS pun memiliki persentase yang positif. Hal ini berarti AS merupakan negara dengan tingkat perekonomian yang tinggi. Kegley dan Raymond menyatakan bahwa tingkat ekonomi negara mempengaruhi kapasitas negara tersebut dalam mencapai tujuan kebijakan luar negerinya, semakin maju perekonomian negara maka akan 
semakin aktif negara tersebut dalam politik global karena adanya kepentingan-kepentingan yang ingin dicapai (Kegley \& Raymond, 2009).

Oleh karena itu, penulis menyimpulkan bahwa aspek ini berpengaruh terhadap proses pembuatan keputusan keluarnya AS dari perjanjian JCPOA. Hal ini dikarenakan AS memiliki kapasitas ekonomi yang kuat untuk mengambil keputusan keluar dari perjanjian JCPOA dalam rangka mencapai tujuan kebijakan luar negerinya. Perekonomian AS yang sangat kuat dan tidak memiliki ketergantungan terhadap Iran tidak akan terpengaruh bila keputusan tersebut berdampak pada pengembalian sanksi atas Iran dan perusahaan AS yang harus menutup bisnisnya di negara tersebut.

\section{Dukungan Kuat dari Parlemen AS}

Dalam pengambilan keputusan terkait hubungan luar negeri terdapat dua cabang kekuasaan yang memiliki fungsi dan tanggung jawab terhadap kebijakan luar negeri AS yaitu cabang eksekutif atau Presiden dan jajaran kabinetnya dan cabang legislatif atau Kongres AS. Peran utama Kongres AS dalam pembuatan kebijakan luar negeri adalah mengubah, menolak atau menerima kebijakan yang diusulkan oleh presiden (Johnson, 2013). Konstitusi AS juga memungkinkan Kongres AS memiliki kewenangan untuk mengumpulkan dan mendukung tentara, mengusir invasi dan menyatakan perang terhadap negara lain (Kollman, 2015). Oleh karena itu penting untuk melihat peta politik dalam Kongres AS terkait keputusan keluar dari perjanjian JCPOA.

Pada masa pemerintahan Barack Obama dimana AS menyepakati JCPOA di tahun 2015, Kongres AS baik di House of Senate maupun House of Representatives secara mayoritas dikuasai oleh Partai Republik. Komposisi Senat Kongres AS pada masa Obama yaitu sebanyak 54 kursi dipegang oleh Partai Republik, 44 kursi oleh Partai Demokrat, dan 2 lainnya dari jalur independen. Lalu untuk House of Representatives, sebanyak 248 kursi diduduki oleh Partai Republik dan 192 lainnya diduduki oleh perwakilan Partai Demokrat (Manning, 2016). Meskipun dianggap sebagai perjanjian bersejarah dan paling sukses bagi Amerika Serikat dalam sejarah negosiasi dengan Iran, perjanjian JCPOA dari sisi domestik mendapatkan banyak resistensi. Tercatat terdapat tiga kali upaya di tingkat Senat AS untuk menggagalkan perjanjian yang telah disepakati pada Juli tahun 2015 itu.

Tabel 4. Upaya House of Senate AS Menggagalkan Perjanjian JCPOA Tahun 2015

\begin{tabular}{|c|c|c|}
\hline Tanggal & Hasil Sidang Senat & Vote Dibutuhkan \\
\hline 10 September 2016 & 58 Yes -42 No & 60 Yes \\
\hline 15 September 2016 & 56 Yes $-42 \mathrm{No}$ & $60 \mathrm{Yes}$ \\
\hline 17 September 2016 & 56 Yes $-42 \mathrm{No}$ & $60 \mathrm{Yes}$ \\
\hline
\end{tabular}

Sumber: Diadopsi dari Laporan Ballotpedia (Ballotpedia.org, 2018)

Upaya Kongres AS untuk menggagalkan kesepakatan terlibatnya AS dalam implementasi perjanjian JCPOA tidak berhasil dilakukan karena membutuhkan setidaknya 60 anggota yang memberikan persetujuan (yes) terhadap usulan yang diajukan. Hasil sidang tersebut membuat keputusan Amerika Serikat tetap dapat ambil bagian sebagai negara yang menyepakati dan mengimplementasikan perjanjian JCPOA dengan status sebagai sebuah executive agreement. Meskipun gagal, hal ini mengindikasikan perjanjian JCPOA yang disepakati AS oleh pemerintahan Obama tidak sepenuhnya diterima oleh unsur pemerintahan lain di dalam negeri.

Pengaruh resistensi yang kuat terhadap perjanjian JCPOA di dalam Kongres AS ini ternyata berlanjut hingga pergantian pemerintahan pasca pemilu 2016. Pada masa pemerintahan Presiden Donald Trump, sebenarnya tidak ada perubahan mayoritas 
pemegang kursi dalam Kongres AS jika dibandingkan dengan masa pemerintahan Presiden Obama. Senat AS di masa Trump memiliki komposisi sebanyak 51 kursi dipegang oleh Partai Republik, 47 kursi oleh Demokrat, dan 2 kursi lainnya tetap dari jalur independen (Manning, Membership of the 115th Congress: A Profile, 2018). Namun resistensi terhadap perjanjian JCPOA tetap kuat dimana secara umum Kongres AS dari partai Republik menyambut baik keputusan pemerintahan Trump untuk mengeluarkan AS dari perjanjian JCPOA.

Tabel 5. Perbandingan Komposisi Anggota Kongres AS Masa Pemerintahan Obama dan Trump

\begin{tabular}{|l|c|c|}
\hline & Obama Administration & Trump Administration \\
\hline & 54 Republicans & 51 Republicans \\
House of Senate & 44 Democrats & 47 Democrats \\
\hline \multirow{3}{*}{ House of Representatives } & 2 Independents & 2 Independents \\
\hline
\end{tabular}

Sumber: Diadopsi dari Laporan Congressional Research Service (Manning, 2016 \& 2018)

Apabila kita perhatikan tabel diatas, maka cenderung sulit bagi Partai Demokrat sekalipun jika mereka ingin menghalangi keputusan Trump untuk memutuskan AS keluar dari perjanjian JCPOA. Partai Demokrat setidaknya membutuhkan 13 suara tambahan dari anggota Senat yang berasal dari Partai Republik. Hal yang sangat sulit mengingat suara Partai Republik cukup solid terutama dalam menentang perjanjian JCPOA pada tahun 2015 lalu. Resistensi serupa juga ditunjukkan Partai Republik saat wacana AS keluar dari perjanjian JCPOA mulai menyeruak di awal tahun 2018.

Mitch McConnell selaku pimpinan Partai Republik dalam Senat AS menyatakan bahwa mendukung dan berbagi komitmen dengan Presiden Trump bahwa JCPOA adalah kesepakatan yang cacat karena tidak sesuai dengan kepentingan keamanan nasional AS dan Iran tidak seharusnya dapat mengembangkan senjata nuklir (The New York Times, 2018). Hal senada juga diungkapkan oleh Kevin McCarthy selaku pimpinan Partai Republik dalam House of Representatives yang menyatakan bahwa mempercayai Presiden Trump untuk membuat suatu tindakan agar Iran tidak memiliki senjata nuklir, termasuk dalam hal ini mengeluarkan AS dari perjanjian JCPOA dan memberikan sanksi pada Iran (Holpuch, 2018). Beberapa anggota Kongres AS lain juga mendukung wacana keluar dari perjanjian JCPOA yang diantaranya adalah James E. Risch yang merupakan Ketua Subcommittee on Near East, South Asia, Central Asia, and Counterterrorism Senat AS, Ileana Ros-Lehtinen selaku ketua Subcommittee on Middle East and North Africa House of Representatives, Marco Rubio sebagai anggota Committee of Foreign Relations Senat AS, dan Paul Ryan selaku Ketua House of Representatives Amerika Serikat (The White House, 2018).

Komposisi Kongres AS yang mayoritas dipegang oleh anggota dari Partai Republik pengusung Presiden Trump ini mengakibatkan tidak adanya hambatan berarti dari Kongres AS untuk mencegah keputusan AS keluar dari perjanjian JCPOA. Kuatnya dukungan dari anggota Partai Republik yang memegang jabatan-jabatan penting di Kongres AS membuat keputusan AS untuk keluar dari perjanjian JCPOA semakin terbuka. Hal-hal yang telah dijelaskan diatas mengakibatkan bertambahnya kapasitas lembaga eksekutif AS dalam hal ini pemerintahan Donald Trump dalam membuat keputusan mengeluarkan AS dari perjanjian JCPOA.

Pengarub Kelompok Kepentingan Pengusung Donald Trump 
Dalam isu nuklir Iran, secara umum kelompok-kelompok kepentingan di AS terbagi menjadi dua kubu antara pendukung JCPOA dan penentang JCPOA. Kelompok-kelompok kepentingan yang mendukung perjanjian JCPOA rata-rata berkoalisi di belakang upaya-upaya yang dilakukan oleh J-Street, sebuah organisasi berbasis Yahudi-Amerika (Palmer \& Parti, 2018). Bentuk dukungan J-Street terhadap JCPOA diwujudkan melalui kampanye dan pengiklanan di media televisi AS yang menghabiskan dana sebesar 5 Juta USD yang berfokus di lima negara bagian. Selain itu, J-Street juga terlibat sebanyak 125 pertemuan dengan anggota Kongres AS untuk menjaga kesepakatan JCPOA tidak digagalkan oleh cabang legislatif negara tersebut (Chang, 2015).

Kelompok lain yang sangat aktif mendukung perjanjian JCPOA adalah National Iranian American Council (NIAC) yang memiliki sekitar 5000 anggota (Toosi, 2018). NIAC merupakan sebuah organisasi yang didedikasikan untuk memperkuat suara orang-orang Amerika berdarah Iran dan mempromosikan kesalingpahaman yang lebih besar antara orangorang Amerika dan Iran (NIAC, 2018). Pada masa pemerintahan Obama, NIAC tercatat telah mengunjungi Gedung Putih sebanyak 30 kali untuk mempengaruhi keputusan AS terhadap isu nuklir Iran (Middle East Monitor, 2017). Sedangkan pada masa pemerintahan Trump, NIAC melakukan mobilisasi massa pada Januari 2018 untuk berunjuk rasa agar pemerintahan Trump tidak membuat kebijakan yang mengeluarkan AS dari perjanjian JCPOA (Crowley \& Johnson, 2018).

Sedangkan kelompok yang paling keras menentang kesepakatan JCPOA adalah American Israel Public Affairs Committee (AIPAC), sebuah organisasi lobbyist yang mengadvokasi agar kebijakan AS lebih pro terhadap Israel. AIPAC di tahun 2015 dilaporkan menyiapkan anggaran sebesar 20-40 Juta USD untuk kegiatan-kegiatannya dalam rangka menggagalkan keikutsertaan AS mengimplementasikan JCPOA (Rosenberg, 2015). Dana tersebut digunakan dalam berbagai upaya menerbitkan iklan di surat kabar dan televisi, mengorganisir demonstrasi dan membiayai perjalanan anggota AIPAC ke Washington untuk melobi pemerintah khususnya legislator. Selain itu, AIPAC juga tercatat melakukan sebanyak 400 kali pertemuan dengan anggota Kongres AS. Dalam hal pengiklanan di televisi, AIPAC dan sekutunya dalam laporan Sunlight Foundation dilaporkan setidaknya membeli ruang iklan televisi di 23 negara bagian AS (Chang, 2015).

Kelompok kepentingan lain seperti The Republican Jewish Coalition (RJC) pada tahun 2015 merespon cepat keputusan pemerintahan Obama yang menyepakati JCPOA, dengan cara mendorong 40.000 anggotanya untuk menghubungi dan mendesak anggota Kongres AS yang memiliki latar belakang yahudi atau yang memiliki konstituen yang cukup besar dari komunitas yahudi untuk menolak perjanjian JCPOA (Ho, 2015). Sedangkan kelompok lain yaitu Christians United for Israel (CUFI) dengan anggota sebanyak 2,2 Juta orang dilaporkan bergerak aktif mendatangi dan memberikan surat kepada anggota Kongres AS khususnya yang dari Partai Demokrat untuk memperingatkan betapa berbahayanya jika AS tetap ikut serta dalam kesepakatan JCPOA (Labott, Walsh, \& Serfaty, 2015). Melalui surat elektronik saja, anggota CUFI terhitung telah mengirimkan sebanyak 100.000 pesan elektronik kepada anggota Kongres untuk menolak perjanjian JCPOA. Selain aktif juga melobi Kongres, CUFI juga dikabarkan mengajak sebanyak 1.500 pastur yang merupakan anggota mereka untuk dapat memperkuat pesan-pesan penolakan kesepakatan JCPOA dalam ceramah-ceramah ketika pelaksanaan ritual keagamaan dilangsungkan.

Selain AIPAC, CUFI, dan RJC juga terdapat kelompok lainnya yang menentang perjanjian JCPOA yaitu United Against Nuclear Iran (UANI) dan The Israel Project. UANI sejak tahun 2013 dilaporkan memiliki dana sebesar 500.000 USD untuk mengkampanyekan penolakan perjanjian JCPOA melalui media seperti televisi, radio, koran, dan media digital. Sedangkan The Israel Project dilaporkan menggunakan dana sebesar 1 Juta USD untuk 
melakukan lobi penentangan terhadap perjanjian JCPOA melalui sosial media dan pembuatan situs web (Ho, Mega-Donors Opposing Iran Deal Have Upper Hand In Fierce Lobbying Battle, 2015). Jika dilihat dari jumlah maka kelompok-kelompok kepentingan yang menentang perjanjian JCPOA memiliki jumlah yang lebih banyak dibanding yang mendukung. Hal ini tentu menjadi pertimbangan bagi pemerintahan AS dalam menentukan keputusannya terkait perjanjian JCPOA.

Pada masa pemerintahan Trump kelompok-kelompok yang menentang kesepakatan tetap melakukan upaya lobi atas kesepakatan JCPOA. Juru bicara AIPAC, Marshall Wittmann menyatakan "Our principal objectives have been and remain preventing Iran from obtaining nuclear weapons capability and deterring its malign regional behavior" (Wilner, 2017). Pernyataan tersebut memperlihatkan posisi AIPAC sebagai kelompok terdepan dalam menentang JCPOA yang belum berubah di masa pemerintahan Trump. Hal ini diperkuat juga ketika AIPAC melaksanakan pertemuan tahunan pada bulan Maret 2018. Pada pertemuan itu pembicara-pembicara yang hadir mengkritisi dan menegaskan kepada pemerintahan Trump untuk mengambil pendekatan yang lebih tegas terhadap kesepakatan JCPOA. Selain itu, pernyataan sikap tersebut juga memperlihatkan bahwa upaya-upaya penentangan terhadap perjanjian JCPOA tetap berjalan dalam masa pemerintahan Trump.

Pada dasarnya, hal yang masih tidak dapat diterima oleh AIPAC adalah bagian sunset clause JCPOA yang dinilai dapat membuat Iran memulai kembali program pengayaan nuklirnya dalam jangka waktu satu dekade kedepan. Selain itu AIPAC juga menilai bahwa terdapat blind spot pada situs militer Iran dalam pemeriksaan yang dilakukan IAEA terkait kepatuhan Iran atas kesepakatan JCPOA. Namun, mengingat kegagalan mempertahankan dukungan bipartisan untuk menghentikan keikutsertaan AS dalam perjanjian JCPOA di tahun 2015, AIPAC mengubah strateginya pada tahun 2017 dengan menyoroti perilaku agresif Iran di Timur Tengah untuk kemudian mengkambing-hitamkan JCPOA (Wilner, 2017). Tidak heran apabila pemerintahan Trump kerap kali ini menyoroti juga aktivitas destabilisasi Iran di Timur Tengah ketika membahas mengenai perjanjian JCPOA.

Besarnya jumlah anggota dan kekuatan kelompok-kelompok kepentingan yang anti terhadap perjanjian JCPOA serta kurang seimbangnya kekuatan dan perlawanan dari kelompok kepentingan yang mendukung JCPOA membuat pemerintah AS yang dipimpin Donald Trump pada akhirnya membuat AS memiliki dorongan yang lebih besar untuk keluar dari perjanjian JCPOA. Keberadaan kelompok kepentingan yang menentang JCPOA membuat pemerintah AS memiliki dukungan masyarakat yang cukup yang bersumber dari kelompok-kelompok kepentingan tersebut. Hal ini sebagaimana diungkapkan oleh Cavalli, meskipun presiden memegang peran paling signifikan namun dalam pembuatan kebijakan luar negeri AS, kongres, kelompok kepentingan, dan opini publik juga memiliki pengaruh (Cavalli, 2013).

\section{Opini Publik Negatif Warga AS Terhadap Iran}

Secara umum, opini publik AS terhadap Iran cukup negatif. Hal ini ditunjukkan dengan persepsi masyarakat AS yang sebagian besar menganggap Iran adalah ancaman yang sangat serius bagi keamanan negaranya. Sementara itu, hanya sebagian kecil saja persentase masyarakat AS yang tidak menganggap Iran sebagai ancaman. Hal ini tentu merupakan konsekuensi dari dinamika hubungan enmity AS-Iran yang terbangun sejak lama. Opini publik AS terhadap persepsi ancaman Iran dapat dilihat pada gambar dibawah ini yang penulis ambil berdasarkan hasil polling yang dilakukan oleh SSRS CNN. 
Gambar 5. Opini Publik Amerika Serikat Terhadap Persepsi Ancaman Iran

\begin{tabular}{|l|c|c|c|c|c|}
\hline Iran & $\begin{array}{c}\text { Very serious } \\
\text { threat }\end{array}$ & $\begin{array}{c}\text { Moderately } \\
\text { serious threat }\end{array}$ & $\begin{array}{c}\text { Just a slight } \\
\text { threat }\end{array}$ & No threat at all & No opinion \\
\hline May 02-05, 2018 & $40 \%$ & $35 \%$ & $15 \%$ & $7 \%$ & $3 \%$ \\
\hline October $12-15,2017$ & $30 \%$ & $39 \%$ & $16 \%$ & $11 \%$ & $4 \%$ \\
\hline
\end{tabular}

Sumber: Diadopsi dari Laporan Hasil Survey SSRS CNN (SSRS, 2018)

Terkait dengan JCPOA, opini publik AS terhadap kepatuhan Iran juga dinilai negatif. Masih berdasarkan polling yang sama, mayoritas menganggap Iran melakukan pelanggaran terhadap JCPOA. Hal ini cukup ganjil pasalnya sejak perjanjian disepakati Iran dinyatakan patuh berdasarkan inspeksi yang dilakukan oleh IAEA. Pelanggaran mulai dilakukan oleh Iran justru pasca AS keluar dari perjanjian JCPOA. Gambar dibawah ini menunjukkan tingkat opini publik AS terhadap kepatuhan Iran dalam perjanjian JCOA.

Gambar 6. Opini Publik Amerika Serikat Terhadap Kepatauhan Iran dalam Perjanjian JCPOA

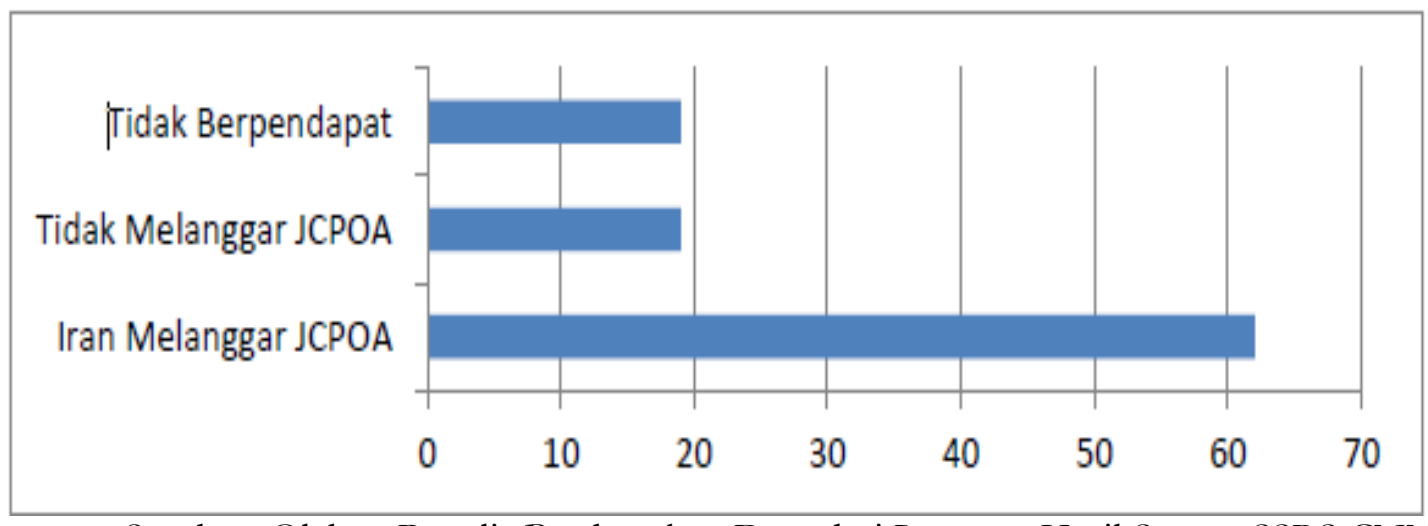

Sumber: Olahan Penulis Berdasarkan Data dari Laporan Hasil Survey SSRS CNN

(SSRS, 2018)

Meskipun opini publik AS di dua kategori tersebut mengindikasikan persepsi negatif, hal berbeda ditunjukkan dalam hal pendapat mengenai haruskah AS keluar dari perjanjian JCPOA. Menurut survei yang dilakukan oleh SSRS, mayoritas publik AS berpendapat bahwa AS seharusnya tetap mengikuti perjanjian JCPOA dengan persentase sebesar $63 \%$. Sedangkan publik AS yang berpendapat bahwa negaranya harus keluar dari JCPOA persentasenya hanya sebesar 29\%. Namun, persentase tersebut mengalami kenaikan sebesar 2\% jika dibandingkan dengan survei sebelumnya yang dilakukan bulan Oktober 2017. Gambar dibawah ini menunjukkan persentase opini publik AS terhadap keputusan mana yang harus negaranya ambil terkait dengan perjanjian JCPOA. 
Gambar 7. Opini Publik Amerika Serikat Terhadap Kepatauhan Iran dalam Perjanjian JCPOA

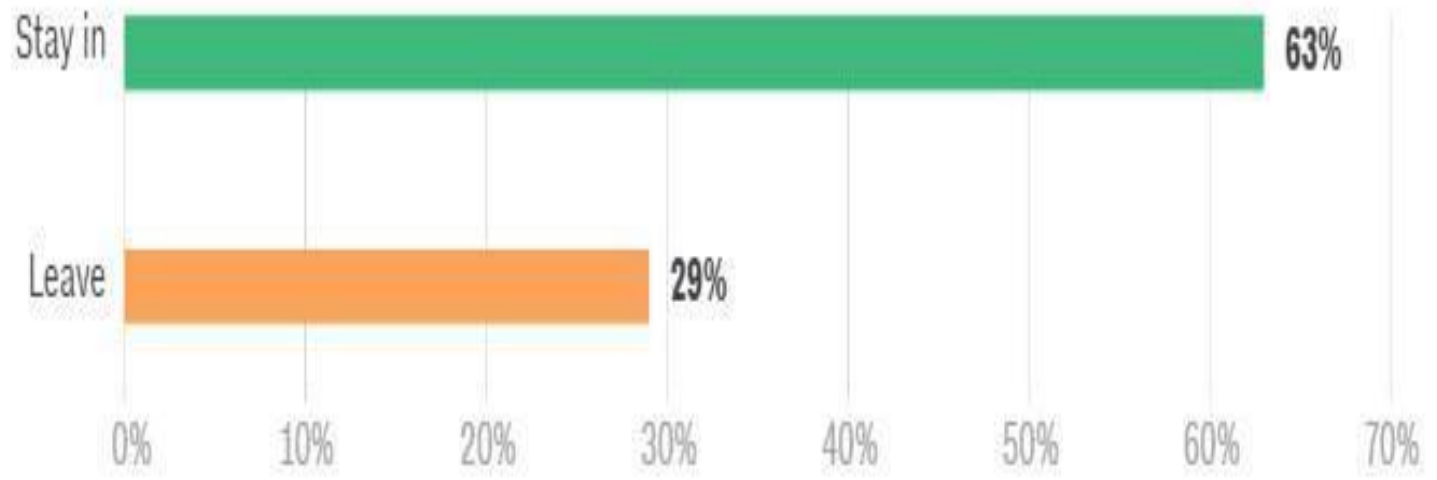

Sumber: Diadopsi dari Survey SRSS CNN (Sparks, 2018)

Berdasarkan survei sebagian besar publik AS tidak menginginkan negaranya keluar dari perjanjian JCPOA. Namun demikian, peningkatan opini publik yang yang cukup besar terkait persepsi Iran sebagai sebuah ancaman yang sangat serius bagi keamanan AS tentu menjadi faktor penting bagi pemerintah AS dalam proses pengambilan keputusan. Melalui perbandingan ketiga hal tersebut, penulis menyimpulkan bahwa publik AS memiliki persepsi negatif terhadap Iran karena menilai Iran sebagai ancaman serius bagi keamanan negaranya dan menganggap Iran melakukan pelanggaran dalam implementasi perjanjian JCPOA. Hal inilah yang menjadi pertimbangan pemerintah AS dalam keputusannya keluar dari perjanjian JCPOA.

\section{Iran-Hawkish dalam Jajaran Pemerintahan AS}

Pejabat-pejabat kunci dalam jajaran kabinet pemerintahan Trump mayoritas sependapat bahwa Iran telah melakukan aktivitas destabilisasi keamanan yang berbahaya di Timur Tengah melalui penyebaran pengaruh dan proxy war. Namun terdapat perbedaan pendapat dalam memandang status AS dalam perjanjian JCPOA. Perbedaan pandangan ini berfokus kepada pertanyaan 'apakah AS harus keluar dari perjanjian JCPOA dan mengambil langkah unilateral yang lebih tegas terhadap Iran' yang muncul akibat agresivitas Iran di Timur Tengah. Beberapa pejabat seperti Menteri Luar Negeri Rex Tillerson, Menteri Pertahanan James Mattis, National Security Advisor H.R. McMaster, Kepala Staf Gedung Putih John Kelly, dan Kepala Staf Gabungan Militer AS Joseph Dunford adalah nama-nama yang berpandangan bahwa AS harus tetap menjadi bagian dari JCPOA.

Departemen Luar Negeri AS ketika dipimpin oleh Rex Tillerson bahkan pernah mendapat cap sebagai rawa-rawa atau "the swamp" oleh kantor kepresidenan Trump (Winter, Gramer, \& Luce, 2017). Hal ini terjadi karena Rex Tillerson menjadi aktor penting dalam memberi nasihat kepada Trump terkait penerbitan sertifikasi kepatuhan Iran yang ditujukan kepada Kongres AS setiap 90 hari (Labott \& Cohen, 2017). Sebelum keluar dari perjanjian JCPOA, terutama ketika Deplu AS dalam kepemimpinan Rex Tillerson, pemerintahan presiden Trump selalu memberikan sertifikasi atas kepatuhan Iran dalam perjanjian JCPOA meskipun terlihat setengah hati. Hal ini dikarenakan pada dasarnya Presiden Trump seringkali menugaskan Deplu AS untuk mempersiapkan kemungkinan melakukan desertifikasi terhadap kepatuhan Iran dalam perjanjian JCPOA.

Pejabat kunci lain seperti H.R. McMaster yang merupakan National Security Advisor (NSA) juga melakukan hal serupa sehingga dianggap sebagai penghambat. Dalam beberapa kesempatan, McMaster diketahui mengundang beberapa senator partai demokrat untuk 
mendiskusikan perjanjian JCPOA terutama terkait rencana Trump yang ingin memberikan desertifikasi atas kepatuhan Iran dalam perjanjian tersebut (Liptak, Cohen, \& Labott, 2017). Pendekatannya kepada anggota legislatif AS ini ditujukan untuk mengurangi gangguan dari sisi legislatif agar Presiden Trump dapat membuat AS tetap dalam perjanjian JCPOA (Woodruff \& Ackerman, 2018). Pada akhirnya, kedua pejabat kunci ini tidak bisa membendung pendirian kubu penentang JCPOA, mereka berdua dicopot dari jabatannya. Tillerson bukan lagi Menteri Luar Negeri AS sejak Maret 2018, sementara McMaster berhenti satu bulan berikutnya. Posisi mereka kemudian digantikan oleh Mike Pompeo yang dialihtugaskan dari Direktur CIA menjadi Menteri Luar Negeri. Sementara posisi National Security Advisor diisi oleh John Bolton. Keduanya merupakan hardliner penentang Iran, tidak terkecuali perjanjian JCPOA.

Ketika masih menjabat sebagai Direktur CIA, Pompeo diketahui memberikan nasihat kepada presiden Trump pada bulan Juli 2017 untuk menyatakan bahwa perjanjian JCPOA tidak mengakomodasi kepentingan keamanan nasional AS (Hennigan, Bennett, \& Wilkinson, 2017). Pompeo menilai perjanjian JCPOA bersifat jangka jangka pendek dan hanya membendung sebagian kecil ancaman yang ditimbulkan oleh Iran (The Aspen Institute, 2017). Ia menilai bahwa perilaku Iran sebagai negara semakin memburuk setelah adanya perjanjian JCPOA seperti melancarkan serangan siber, mempersenjatai pemberontak Houthi di Yaman, dan memberi dukungan kepada rezim Presiden Suriah Bashar al-Assad yang dinilai merupakan rezim pembunuh (McKenzie, 2018). Hal ini diakibatkan adanya ambisi Iran untuk menjadi hegemon di Timur Tengah (CIA, 2017). Menurutnya, untuk mencapai ambisi tersebut, Iran telah bertindak sangat agresif karena telah menggunakan dan menjadi gembong pasukan-pasukan proksi untuk memperluas pengaruhnya di Timur Tengah (Tanter, 2017).

Sedangkan untuk posisi NSA, John Bolton dan dikenal sebagai sosok yang memiliki pendekatan sangat keras terhadap Iran dan Korea Utara (Brook \& Korte, 2018). Bolton bahkan pernah menulis sebuah artikel berjudul "untuk menghentikan bom Iran, maka bomlah Iran" yang ditujukan untuk mengkritik pemerintahan Obama karena menyepakati perjanjian JCPOA (Carey, 2018). Ia adalah sosok yang teguh memberikan perlawanan terhadap sebagian besar bentuk diplomasi multilateral AS terhadap Iran yang dianggapnya sebagai tanda kelemahan. Menurutnya, Trump seharusnya bisa membebaskan AS dari perjanjian JCPOA di kesempatan paling awal (Borger, Iran Nuclear Deal Talks Persist As Trump Looks Poised To Kill It, 2018). Dia juga menilai, upaya-upaya yang dikerahkan untuk membujuk Presiden Trump agar tetap bertahan dalam perjanjian tersebut dinilai hanya membahayakan AS (Bolton, 2017). Pada dasarnya, antipati Bolton terhadap JCPOA ini muncul akibat Ia menganggap perjanjian JCPOA masih menyediakan ruang bagi Iran untuk melanjutkan penelitian, pengembangan dan pemrosesan nuklirnya serta mekanisme pengawasan dalam JCPOA tidak memadai (The White House, 2018).

Pejabat lain yang menentang perjanjian JCPOA dan menilai bahwa AS perlu keluar dari perjanjian JCPOA antara lain adalah Duta Besar AS untuk PBB yaitu Nikki Haley dan Stephen Miller yang menjabat sebagai Penasihat Senior Presiden, mereka adalah pengkritik keras perjanjian JCPOA (DW, 2017). Selain itu ada Steve Bannon (Kepala Ahli Strategis Kepresidenan) dan Sebastian Gorka (Deputi Asisten Presiden) yang dikenal sebagai penasihat Trump paling berperan dalam meyakinkan presiden untuk lebih banyak memberi tekanan kepada rezim Iran, untuk menghentikan partisipasi AS dari JCPOA, dan mendorong pemberian sanksi kepada Iran (ISN Security Watch, 2017). Banyaknya pimpinan organisasi birokrasi pemerintahan Trump yang menentang perjanjian JCPOA ini berpengaruh mendorong pertimbangan dalam proses pembuatan kebijakan AS keluar dari perjanjian nuklir JCPOA. 


\section{Orientasi Kebijakan American First}

Donald Trump menetapkan orientasi kebijakan luar negeri AS yang disebut dengan “America First" yang berfokus pada upaya untuk mengedepankan kepentingan dan keamanan warga AS sebagai prioritas pertama. America First memandang pencapaian perdamaian perlu dilakukan melalui pendekatan kekuatan dengan melakukan modernisasi angkatan bersenjata, pengembangan nuklir dan rudal balistik AS. Hal ini dilakukan karena pemerintahan Trump meyakini bahwa bersiap untuk perang adalah salah satu cara paling efektif untuk menjaga perdamaian. Pada awal tahun 2017, Trump pernah menyatakan bahwa menahan penyebaran islam radikal menjadi tujuan besar dari kebijakan luar negeri AS, bahkan bila perlu kekuatan militer akan digunakan dalam mencapai tujuan itu (The White House, 2018). Menurut Cordesman ini adalah upaya untuk mengembalikan dominasi kekuatan militer AS di tingkat global, dengan tujuan untuk menahan, menghalangi, dan mengalahkan ancaman yang ditimbulkan dari Rusia, Tiongkok, Iran, dan Korea Utara (Cordesman, 2018).

Pada isu Timur Tengah, Trump memfokuskan pemerintahannya untuk mengembalikan kepemimpinan AS di Timur Tengah, mempererat kembali hubungan dengan Israel, dan mengedepankan tindakan tegas untuk menentang agresor di kawasan tersebut. Dalam hal menentang agresor di kawasan Timur Tengah, Trump menentang segala aktivitas destabilisasi Iran dan memberikan sanksi kepada Iran dan entitas yang terkait dengan negara tersebut (The White House, 2018). Fokus Trump terhadap Iran ini kemudian diformulasikan kedalam sebuah strategi khusus yang diterapkan untuk menghadapi ancaman Iran. Terdapat empat poin utama dalam strategi yang diterapkan Trump terhadap Iran. Pertama, AS memprioritaskan untuk melawan aktivitas Iran dalam memberi dukungan kepada kelompok teroris di kawasan Timur Tengah. Kedua, AS bertekad melawan aktivitas pendanaan Iran kepada kelompok-kelompok teror dengan memberikan sanksi-sanksi tambahan. Ketiga, menjalankan upaya-upaya untuk menangani proliferasi rudal balistik yang dilakukan oleh Iran karena hal ini mengancam negara tetangga, perdagangan global, dan kebebasan navigasi. Keempat, mencegah segala kemungkinan rezim Iran dari memperoleh senjata nuklir (The White House, 2017). Sedangkan secara khusus terkait perjanjian JCPOA, Presiden Trump sejak masa kampanye menganggap perjanjian tersebut adalah kesepakatan terburuk yang pernah dibuat AS (Torbati, 2016). Ketika menjabat sebagai Presiden AS, dia mengeluarkan tiga tuntutan untuk memperbaiki perjanjian tersebut. Tuntutan pertama adalah terkait "sunset clause" yang mana Trump menginginkan agar pembatasaan program nuklir Iran tidak memiliki batasan waktu, karena khawatir Iran dapat menciptakan senjata nuklir di kemudian hari. Kedua, Trump menuntut agar Iran dapat memberikan izin yang lebih luas bagi IAEA dalam pemeriksaan program nuklir milik Iran. Tuntutan Ketiga adalah pelarangan bagi pengembangan dan percobaan rudal balistik milik Iran (Ellyatt, 2018).

\section{Pandangan Negatif Trump Terhadap Pemimpin Iran}

Relasi antara Trump dan Rouhani dapat dikatakan sangat dingin yang disebabkan oleh kritik-kritik Trump terhadap Iran yang tidak bisa diterima oleh Rouhani. Pada Sidang Umum PBB tahun 2017 Trump menyatakan perjanjian JCPOA adalah kesepakatan terburuk yang pernah dibuat. Rouhani pun merespon pernyataan Trump dengan mengatakan "It will be a great pity if this agreement were destroyed by rogue newcomers to the world of politics" (Gaouette, 2017). Pernyataan Rouhani tersebut disampaikan pada kesempatan yang sama yaitu Sidang Umum PBB tahun 2017, untuk menandingi kecaman dari Trump terhadap Iran dan perjanjian JCPOA. Dengan kata lain, pimpinan Iran juga berani untuk mengimbangi perilaku Trump. Pada kesempatan itu Rouhani juga menyatakan bahwa jika AS keluar dari perjanjian 
JCPOA maka kredibilitas AS dalam politik global akan rusak karena dianggap tidak mampu menepati kesepakatan.

Sedangkan Trump melontarkan kritik terhadap Iran yang disampaikan dalam Sidang Umum PBB tahun 2017, kritiknya ditujukan untuk menyerang sistem pemerintahan Iran yang dinilai hanyalah kedok palsu bagi kediktatoran korup yang berkuasa di negara tersebut. Trump menyatakan "The Iranian government masks a corrupt dictatorship behind the false guise of a democracy. It has turned a wealthy country with a rich history and culture into an economically depleted rogue state whose chief exports are violence, bloodshed, and chaos" (The White House, 2017). Ini merupakan sebuah peperangan pernyataan dan kritik yang mengindikasikan pandangan negatif Trump terhadap kepemimpinan pemerintah Iran. Pada kesempatan yang sama Trump juga mengkritik aktivitas pengembangan rudal balistik Iran, pendanaan yang dilakukan Iran untuk mendukung kelompok teroris seperti Hizbullah, pemberian dukungan terhadap rezim Bashar Al-Assad di Suriah, dan aksi-aksi penyerangan melalui strategi proksi kepada negara tetangganya seperti Israel dan banyak negara Arab.

Sedangkan terkait perjanjian JCPOA, Trump menyatakan perjanjian tersebut adalah kesepakatan terburuk dan paling sepihak yang pernah dibuat AS. Trump mengatakan "The Iran Deal was one of the worst and most one-sided transactions the United States has ever entered into. Frankly, that deal is an embarrassment to the United States" (The White House, 2017). Pandangan ini muncul bukan tanpa sebab, Donald Trump sendiri memandang perjanjian JCPOA perlu diperbaiki. Oleh karena itu sebagaimana disebutkan sebelumnya, Donald Trump menuntut tiga perbaikan dalam perjanjian JCPOA. Terkait kritik Trump tersebut, Rouhani menilai Trump sebagai pemimpin AS dalam pemerintahannya hanyalah mencari-cari alasan untuk merusak kesepakatan yang telah dicapai bersama dalam perjanjian JCPOA. Oleh karena itu, Rouhani menyatakan bahwa tidak logis apabila Iran harus rela melakukan pembicaraan dengan Trump tentang isu-isu lain. Rouhani mengatakan "So after having reached an agreement for years and having obtained and ratified that agreement, we see today that the Americans are seeking an excuse in order to break this agreement, What possible, logical reason would we have to talk to them about any other issues?" (Gaouette, 2017). Pernyataan ini mengindikasikan bahwa Iran enggan untuk melakukan negosiasi ulang untuk merevisi kesepakatan yang ada dalam perjanjian JCPOA.

Pandangan Trump terhadap Ayatollah Ali Khamenei juga dapat dikatakan cukup buruk. Trump menilai bahwa selama 28 tahun Khamenei telah menyebarkan ideologi revolusioner yang bertujuan merusak sistem internasional dan negara-negara lain melalui kekerasan dan subversi. Trump menganggap bahwa Khamenei menempatkan AS sebagai musuh utama bagi Iran yang mana pernah disebut oleh Khamenei sebagai 'The Great Satan' (The White House, 2017). Menurutnya, Khamenei di Iran membuat negara tersebut terus menyebar kekerasan, menggoyahkan negara-negara tetangga Iran, dan mendukung terorisme. Trump menilai Khamenei telah melakukan penindasan kepada rakyat Iran, menyalahgunakan hak-hak warga Iran, membatasi akses internet dan dunia luar. Khamenei juga dianggap telah mencurangi pemilihan umum di Iran, menembak para pengunjuk rasa, dan memenjarakan politisi-politisi berhaluan reformis seperti Mir Hussein Musavi dan Mehdi Karroubi. Semua itu dilakukan Khamenei melalui pengerahan Islamic Revolutionary Guards Corps (IRGC) yang merupakan alat utama yang hanya patuh kepada sang Ayatollah Ali Khamenei.

\section{Besarnya Otoritas Presiden Trump dalam Pengambilan Keputusan}

Presiden AS adalah pemimpin dalam kebijakan luar negeri AS yang memiliki kewenangan sebagai commander-in-chief, chief diplomat, chief administrator, chief legislator, chief judicial officer, dan suara rakyat AS (Rosati \& Scott, 2011). Kewenangan tersebut membuat presiden AS memiliki otoritas untuk mengambil keputusan dalam urusan luar negeri seperti menjalankan perang, menegosiasikan perjanjian, membuat kesepakatan 
dagang, dan hubungan diplomatik.607 Dalam hal perjanjian JCPOA, Trump sebagai presiden AS juga memiliki otoritas untuk mengambil keputusan dalam urusan luar negeri. Namun demikian, penulis juga menilai perlunya melihat status perjanjian JCPOA yang ditandatangani AS dan hubungannya dengan otoritas yang dimiliki Trump dalam memutuskan AS untuk keluar dari perjanjian JCPOA.

Hukum domestik AS mengatur perjanjian internasional kedalam tiga kategori. Kategori pertama adalah treaty yang mana presiden menyepakati suatu perjanjian dengan adanya masukan dan persetujuan Senat (Padeanu, 2016). Kategori kedua adalah sole executive agreement dimana perjanjian disepakati secara independen oleh presiden berdasarkan otoritas konstitusional yang dimilikinya tanpa ada masukan dari Kongres. Sedangkan yang ketiga adalah congressional-executive agreement dimana jenis perjanjian ini melibatkan adanya UU yang dibuat Kongres. UU yang dimaksud disini adalah yang berfungsi untuk mengesahkan dan mengimplementasikan perjanjian yang telah disepakati. Selain itu, presiden juga seringkali menyepakati perjanjian yang tidak mengikat secara hukum namun berlandaskan pada komitmen politik.

Status perjanjian JCPOA di AS sendiri dianggap sebagai kesepakatan berlandaskan komitmen politik saja tanpa mengikat secara hukum dikarenakan Kongres AS tidak secara langsung menyetujui masuknya AS menjadi bagian dari perjanjian JCPOA. Oleh karena itu, Trump sebagai presiden AS memiliki kewenangan untuk mengeluarkan AS dari perjanjian JCPOA dan bahkan mengembalikan sanksi-sanksi AS terhadap Iran (Mulligan, Withdrawal From International Agreements-Legal Framework, The Paris Agreement, And The Iran Nuclear Agreement, 2018). Oleh karena itu, status perjanjian JCPOA yang diadopsi hanya berdasarkan komitmen politik lembaga eksekutif tanpa adanya keterikatan hukum melalui kongres dan otoritas Trump yang besar sebagai chief diplomat yang memimpin AS dalam urusan luar negeri memberikan pengaruh besar dalam memudahkan proses pembuatan keputusan AS keluar dari perjanjian JCPOA.

\section{Proses Pengambilan Keputusan}

\section{Permasalaban dalam Perjanjian JCPOA}

Pemerintahan Donald Trump mengidentifikasi setidaknya terdapat tiga permasalahan dari perjanjian JCPOA. Pertama adalah perjanjian JCPOA tidak mengakomodasi pelarangan bagi program rudal balistik Iran yang mana pengembangan rudal balistik tersebut menggunakan beberapa instrumen yang sama dengan pengembangan nuklir (Mohammed \& Irish, 2018). Diangkatnya sanksi-sanksi ekonomi terhadap Iran dikarenakan perjanjian JCPOA dinilai mengalirkan sejumlah dana segar kepada Iran untuk bisa meningkatkan program rudal balistiknya (The White House, 2018). Program rudal balistik Iran saat ini memang tidak dapat menjangkau wilayah AS, namun sebagaimana ditunjukkan pada Gambar 2. diatas, jangkauan rudal balistik Iran dapat menjangkau kawasan Timur Tengah, Afrika Utara, dan Eropa Timur (CSIS Missile Defense Project, 2020). Hal ini menjadi masalah bagi AS karena aliansinya seperti Arab Saudi dan Israel berada pada radius jangkauan rudal balistik milik Iran.

Kedua adalah perjanjian JCPOA belum bisa membuat IAEA melakukan pemeriksaan nuklir Iran hingga ke lokasi-lokasi yang dicurigai oleh AS (Mohammed \& Irish, 2018). Lokasilokasi tersebut antara lain situs militer, laboratorium dan universitas di Iran (Gatten, 2018). Pemeriksaan hingga ke tempat-tempat tersebut dirasa perlu untuk menghindarkan adanya kecurigaan Iran merahasiakan pengembangan senjata nuklir. Perjanjian JCPOA pada dasarnya menyediakan akses bagi pengawas dari IAEA untuk melakukan pemeriksaan hingga ke situs militer Iran, namun pihak Iran menyatakan tidak akan pernah memberikan akses pemeriksaan ke fasilitas militer. Hal ini kemudian berakibat kepada IAEA yang terus 
menahan diri untuk meminta akses ke situs-situs mencurigakan milik Iran karena khawatir Iran akan menolak (Kruzel, 2018).

Ketiga adalah terkait "sunset clause" dari perjanjian JCPOA yang mana pembatasan program nuklir Iran dibawah perjanjian tersebut yang akan berakhir dalam kurun waktu 10 tahun setelah disepakati. Satu dekade pasca disepakatinya JCPOA, batasan-batasan utama terhadap program nuklir Iran akan secara bertahap mulai diangkat (Vick, 2018). Oleh karena itu, Pemerintah AS menganggap perjanjian JCPOA hanyalah bersifat sementara dan Iran di kemudian hari dapat memulai kembali program nuklirnya dan dikhawatirkan dapat menciptakan senjata nuklir. Hal ini menjadi permasalahan serius bagi pemerintah AS di bawah Trump karena ada keyakinan bahwa jika Iran di kemudian hari memiliki senjata nuklir maka akan membuat negara-negara lain di kawasan Timur Tengah bersiap memperoleh senjata nuklir juga. Keadaan seperti itu membuat Timur Tengah akan berada dalam bahaya perlombaan senjata nuklir.

Selain permasalahan di atas, pemerintah AS juga menganggap perjanjian JCPOA memberi dampak kepada aktivitas destabilisasi yang dilakukan Iran di Timur Tengah (DiChristoper, 2017). Perjanjian JCPOA membuat sanksi-sanksi ekonomi terhadap Iran dicabut yang berdampak pada Iran memiliki akses terhadap dana sebesar 100 Miliar USD termasuk didalamnya dana tunai sebesar 1,8 Miliar USD (The White House, 2018). AS menuding Iran menggunakan dana tersebut untuk aktivitas destabilisasinya di kawasan Timur Tengah. Tudingan tersebut dilatarbelakangi anggapan AS kepada Iran yang menilai negara tersebut sebagai negara pendukung teror di kawasan Timur Tengah terutama di negaranegara seperti Suriah, Yaman, Libanon, Palestina, Irak, dan Afghanistan.

\section{Tujuan AS Mencegah Iran Memiliki Senjata Nuklir Dengan Cara Apapun}

Berdasarkan permasalahan yang telah teridentifikasi, pemerintah AS menetapkan tujuan untuk mencegah segala kemungkinan Iran dapat memiliki senjata nuklir. Sedangkan sasaran yang ditetapkan AS untuk mencapai tujuan tersebut adalah memperbesar akses izin pemeriksaan program nuklir Iran ke semua lokasi yang diminta oleh IAEA. Sasaran yang kedua adalah memastikan bahwa Iran tidak akan pernah memiliki senjata nuklir dengan membuat ketentuan pembatasan program nuklir yang tidak memiliki tanggal kedaluwarsa atau tanpa batasan akhir. Lalu, sasaran ketiga adalah mengatasi permasalahan pengembangan dan pengujian rudal balistik Iran agar tidak dipisahkan dengan senjata nuklir yang harus dibatasi dan dikenakan sanksi juga (The White House, 2018).

Tujuan dan sasaran yang ditetapkan oleh AS dalam mengatasi permasalahan yang ditimbulkan dari perjanjian JCPOA ini pun tidak terlepas dari keadaan politik domestik AS terutama pengaruh dari kelompok kepentingan dan opini publik AS terhadap Iran. Kesepakatan yang dibuat AS dalam perjanjian JCPOA pada tahun 2015 menimbulkan polemik dalam politik domestik AS yang terdapat banyak kelompok kepentingan yang menolak perjanjian tersebut. Sebagaimana telah dijabarkan pada bab empat, beberapa kelompok kepentingan yang kuat seperti AIPAC, CUFI, RJC, UANI, dan The Israel Project memiliki pandangan yang tidak berubah yaitu tetap menentang perjanjian JCPOA. Pada pertemuan tahunan AIPAC di 2018, pembicara-pembicara perwakilan AIPAC yang hadir mengkritisi dan menegaskan kepada pemerintah AS untuk bersikap dan mengambil strategi tegas terhadap perjanjian JCPOA atau jika opsi itu tidak bisa dilakukan, mereka mendorong AS untuk keluar dari perjanjian JCPOA (Younes, 2018).

Sedangkan dari sisi opini publik terhadap Iran, persepsi publik AS terhadap kepatuhan Iran dalam mengimplementasikan perjanjian JCPOA menunjukkan tren negatif sebagaimana ditunjukkan pada Gambar 5-7. Publik AS lebih banyak yang berpendapat bahwa Iran telah melanggar perjanjian JCPOA. Selain itu, opini publik AS terhadap Iran juga dapat dikatakan 
cukup negatif. Sebagian besar publik AS berpendapat bahwa Iran adalah negara yang memberikan ancaman serius bagi negaranya. Besarnya penilaian publik bahwa Iran adalah ancaman sangat serius bagi negaranya tidak berimbang dengan pendapat publik AS yang menganggap Iran hanyalah ancaman kecil ataupun bukan ancaman sama sekali bagi negaranya. Hal ini menunjukkan bahwa warga AS merasa keamanannya terancam oleh Iran, sehingga menjadi pertimbangan yang melatarbelakangi tujuan dan sasaran yang telah ditetapkan pemerintah AS.

Penetapan tujuan untuk mengatasi masalah yang ditimbulkan dari perjanjian JCPOA diatas juga sejalan dengan orientasi kebijakan luar negeri 'America First' yang diterapkan Trump. Kebijakan ini mengedepankan kepentingan keamanan warga AS sebagai prioritas utama (The White House, 2018). Dalam orientasi kebijakan luar negeri tersebut Trump berupaya mencapai perdamaian dengan menggunakan kekuatan. Pemerintah AS mengidentifikasi permasalahan yang ditimbulkan JCPOA berakibat pada meningkatnya aktivitas terorisme di Timur Tengah yang berkaitan dengan dukungan Iran. Permasalahan tersebut berdampak pada keamanan prajurit AS yang bertugas di beberapa negara di Timur Tengah. Pemerintahan Trump sebagaimana ditunjukkan melalui penjelasan diatas sebelumnya memiliki tujuan yang lebih menyeluruh untuk mengatasi permasalahan yang ditimbulkan oleh Iran_(Gladstone, 2017).

\section{Opsi Kebijakan yang Dimiliki AS}

Berdasarkan tujuan yang telah ditetapkan, pemerintah AS memiliki dua pilihan yaitu bertahan namun dengan syarat kelemahan-kelemahan yang terdapat dalam perjanjian JCPOA diperbaiki atau keluar dari perjanjian tersebut. Dalam memperbaiki kelemahan perjanjian JCPOA, pemerintah AS bekerjasama dengan sekutu-sekutunya negara Eropa untuk mengupayakan perbaikan JCPOA dengan dibuatnya perjanjian tambahan baru yang mana perjanjian tambahan ini akan membuat Iran dijatuhi sanksi multilateral jika mengembangkan atau menguji rudal balistik, mencegah pemeriksaan dari IAEA, dan mengembangkan program nuklirnya hingga mampu membuat senjata nuklir (The White House, 2018). Sedangkan terkait pilihan tindakan keluar dari perjanjian JCPOA, pemerintah Amerika Serikat berencana mengambil kebijakan tersebut ketika upaya negosiasi pembuatan perjanjian tambahan dinilai tidak memungkinkan untuk tercapai (Gaouette, 2017).

Pada tanggal 12 Januari tahun 2018 melalui pernyataan resmi yang disampaikan Presiden Amerika Serikat yaitu Donald Trump. Dalam pernyataan tersebut, Donald Trump menyatakan bahwa Amerika Serikat memilih bekerjasama dengan sekutu Eropanya untuk memperbaiki kelemahan-kelemahan perjanjian JCPOA terlebih dahulu. Namun dia juga mengatakan, apabila Amerika Serikat dan sekutu Eropa-nya tidak dapat sepakat membuat perjanjian tambahan maka Amerika Serikat akan segera keluar dari perjanjian JCPOA (The White House, 2018). Dari sini dapat dipahami bahwa AS semula telah mengambil pilihan kebijakan pertama yaitu bertahan dalam perjanjian JCPOA. Dalam menjalankan pilihan kebijakan ini, Amerika Serikat dan negara Eropa sejak awal tahun 2018 melakukan pembentukan kelompok kerja untuk mendiskusikan hal-hal utama yang perlu ada dalam perjanjian tambahan. Kelompok kerja ini bertugas untuk mencari bentuk perjanjian tambahan atau mekanisme lain untuk mengatasi masalah-masalah dalam perjanjian JCPOA (CBS News, 2018).

\section{Deadlock dan Keputusan AS Keluar dari Perjanjian JCPOA}

Upaya AS dan sekutunya yang menjadi bagian kelompok P5+1 yaitu Jerman, Inggris, dan Perancis untuk mengupayakan terakomodasinya tujuan dan sasaran AS dilakukan secara intens juga. Hal ini ditunjukkan dengan komunikasi antara AS dan negara sekutunya juga 
berlangsung di tingkat kepala pemerintahan. Kanselir Jerman dan Presiden Perancis melawat ke Washington untuk menemui Presiden AS. Angela Merkel dan Emmanuel Macron mengunjungi Washington menemui Presiden Trump pada bulan April 2018. Kunjungan kedua kepala pemerintahan sekutu Amerika Serikat itu bertujuan untuk meredam keinginan Trump mengeluarkan Amerika Serikat dari perjanjian JCPOA (Wilkinson \& Bierman, 2018). Presiden Perancis Emmanuel Macron dalam kunjungan tersebut menyampaikan bahwa meskipun Ia dan Trump memiliki pandangan berbeda terkait nilai dari perjanjian JCPOA, Ia menawarkan mekanisme kesepakatan baru dalam empat pilar. Macron menyatakan bahwa JCPOA adalah pilar pertama, dan tiga pilar lainnya adalah perjanjian yang mengatasi permasalahan rudal balistik, keamanan regional, dan program nuklir Iran pasca 2025. Namun, Macron tidak menyampaikan apapun terkait permasalahan "sunset clause" dalam perjanjian JCPOA (Arms Control Association, 2018).

Dalam pertemuan itu, sambutan Trump terhadap perjanjian JCPOA tetap bernada negatif. Meskipun demikian, tampaknya Trump terbuka untuk mempertimbangkan proposal yang ditawarkan Macron dan menyatakan akan mengupayakan pembuatan kesepakatan baru dengan dasar yang kuat (Arms Control Association, 2018). Namun, peluang dilaksanakannya tawaran dari Macron tersebut dikhawatirkan tidak dapat tercapai sebelum batas akhir yang ditetapkan Trump untuk membuat keputusan yaitu tanggal 12 Mei 2018. Sementara itu pada awal Mei, kelompok kerja yang telah dibentuk dikabarkan telah 90 persen mencapai konsensus tentang perjanjian tambahan yang menjadi tuntutan Amerika Serikat untuk bertahan dalam perjanjian JCPOA. Tiga negara Eropa sepakat untuk memberlakukan pembatasan pada program rudal balistik Iran dan mengatasi kegiatan destabilisasi yang dilakukan Iran di Timur Tengah. Namun, konsensus tidak dapat tercapai pada permasalahan "sunset clause" yang mana Amerika Serikat menuntut agar pembatasan produksi bahan bakar nuklir Iran diperpanjang tanpa adanya batasan waktu (Immenkamp, 2018). Tidak tercapainya konsensus untuk membuat perjanjian tambahan ini menjadi pertimbangan bagi Amerika Serikat untuk mengambil pilihan kebijakan yang kedua.

Pada tanggal 8 Mei 2018, Amerika Serikat akhirnya memutuskan menjalankan pilihan kebijakan kedua yaitu keluar dari perjanjian JCPOA dan kembali memberikan sanksi ekonomi kepada Iran. Hal ini sesuai dengan yang telah disampaikan Trump pada bulan Januari 2018 bahwa apabila Amerika Serikat tidak dapat mencapai kesepakatan pembuatan perjanjian tambahan dengan sekutu Eropanya maka Amerika Serikat akan menempuh pilihan kebijakan kedua yaitu keluar dari perjanjian nuklir Joint Comprehensive Plan of Action (JCPOA) dengan Iran. Keputusan AS tersebut disampaikan di Gedung Putih dan kemudian diterbitkan sebagai National Security Presidential Memorandum 11 (NSPM-11). Keputusan ini tidak hanya mengeluarkan AS dari perjanjian JCPOA namun juga mengembalikan sanksi kepada Iran. Belakangan kita sama-sama menyaksikan bahwa keputusan ini mengeskalasi ketegangan IranAS menyusul terjadinya pembunuhan Jenderal IRGC Iran dan aksi balasan serangan rudal Iran ke salah satu markas militer AS di Timur Tengah.

\section{KESIMPULAN}

Keputusan Amerika Serikat terkait perjanjian JCPOA dengan Iran dipengaruhi berbagai macam determinan yang ada pada berbagai tingkatan analisis. Determinan tersebut ditemukan pada sumber internasional, domestik, dan individual. Setiap determinan tersebut menjadi masukan yang dipertimbangkan dalam proses pembuatan kebijakan luar negeri Amerika Serikat terkait perjanjian JCPOA. Pada akhirnya setelah melalui proses pembuatan kebijakan luar negeri berdasarkan procedural rationality, Amerika Serikat pada 8 Mei 2018 memutuskan keluar dari perjanjian nuklir Joint Comprehensive Plan of Action (JCPOA) dengan Iran. 
Pada sumber internasional, aktivitas destabilisasi Iran di kawasan Timur Tengah yang merupakan dampak dari feedback terhadap kebijakan AS sebelumnya yaitu menyepakati perjanjian JCPOA di tahun 2015 memberi pengaruh bagi pengambilan keputusan AS terhadap perjanjian JCPOA di tahun 2018. Aksi agresif Iran di Timur Tengah, seperti pemberian bantuan dan dana kepada kelompok teror, dukungan terhadap rezim Bashar AlAssad di Suriah, dan pengembangan rudal balistik membuat Amerika Serikat menaruh perhatian pada perjanjian JCPOA yang dianggap punya andil bagi aktivitas Iran tersebut. Amerika Serikat menganggap perjanjian JCPOA seharusnya mampu mengurangi aktivitas destabilisasi Iran di kawasan Timur Tengah. Dalam sumber internasional, karakteristik aliansi antara Amerika Serikat dengan negara-negara kelompok P5+1 yang renggang karena tidak adanya ikatan tertentu yang memaksa suatu negara harus mengikuti negara lainnya berpengaruh kepada pengambilan keputusan Amerika Serikat keluar dari perjanjian JCPOA. Dari segi letak geografis dan kondisi geopolitik keberadaan sekutu AS di Timur Tengah seperti Israel dan Arab Saudi juga berpengaruh kepada kebijakan AS karena letak geografis kedua negara tersebut berada dalam jangkauan rudal balistik yang dikembangkan Iran dan terdampak langsung oleh aktivitas destabilisasi Iran di Timur Tengah.

Pada sumber domestik, Amerika Serikat dipengaruhi oleh kapabilitas militer Amerika Serikat yang kuat sehingga berdampak pada keberanian Amerika Serikat untuk mengkonfrontasi Iran dan keluar dari perjanjian JCPOA. Hal lainnya yang berpengaruh adalah kondisi ekonomi Amerika Serikat yang kuat dan tidak memiliki ketergantungan ekonomi dengan Iran sehingga membuat Amerika Serikat tidak akan terkena dampak ekonomi yang merugikan jika keluar dari perjanjian JCPOA. Selain itu, komposisi Kongres yang mayoritas kursinya ditempati oleh Partai Republik yang mengusung Donald Trump sebagai presiden AS juga berpengaruh karena memperkuat kapasitas pemerintahan Trump yang berdampak pada keleluasaan dalam mengambil keputusan keluar dari perjanjian JCPOA.

Faktor determinan lainnya dalam sumber domestik adalah banyaknya kelompok kepentingan yang anti terhadap perjanjian JCPOA seperti AIPAC, CUFI, UANI, The Israel Project dan RJC juga memberikan pengaruh bagi pengambilan kebijakan luar negeri Amerika Serikat. Selain itu, pendapat publik Amerika Serikat yang besar dalam menganggap Iran sebagai ancaman serius bagi negaranya dan pendapat publik yang besar akan ketidakpatuhan Iran dalam mengimplementasikan perjanjian JCPOA juga berpengaruh sebagai determinan terhadap pengambilan keputusan Amerika Serikat keluar dari perjanjian JCPOA. Faktor domestik terakhir yang mempengaruhi pengambilan keputusan AS keluar dari perjanjian JCPOA adalah banyaknya pejabat pemerintahan Amerika Serikat yang dikenal sebagai penentang perjanjian JCPOA yang mengisi posisi penting dalam jajaran kabinet dan penasihat Trump.

Di sumber individu, terdapat beberapa hal yang mempengaruhi diambilnya kebijakan Amerika Serikat keluar dari perjanjian JCPOA. Pertama, Trump yang memiliki orientasi kebijakan luar negeri 'America First' berfokus pada keamanan warga AS memilih menjalankan strategi konfrontatif terhadap Iran. Hal ini dikarenakan Trump ingin mengatasi aktivitas destabilisasi Iran dan menuntut perbaikan perjanjian JCPOA yang dinilai merugikan bagi Amerika Serikat. Sejalan dengan orientasi tersebut Trump memandang perjanjian JCPOA memiliki banyak kelemahan dan memberikan tiga tuntutan untuk memperbaiki tiga kelemahan tersebut. Tiga tuntutan tersebut perlu diperbaiki agar AS dapat bertahan di perjanjian JCPOA dikarenakan apabila perjanjian tersebut tidak diperbaiki maka akan membahayakan keamanan warga AS.

Kedua, Trump memiliki pandangan yang buruk terhadap jajaran kepemimpinan Iran yang Ia nilai menjadi sumber dari segala aktivitas destabilisasi Iran di kawasan Timur Tengah 
sehingga kepercayaannya terhadap Iran menjadi rendah. Ketiga, Trump memiliki otoritas yang besar untuk mengeluarkan AS dari JCPOA karena status perjanjian JCPOA yang disepakati Obama adalah kesepakatan berlandaskan komitmen politik. Menurut hukum AS presiden secara independen berwenang penuh mengambil keputusan terhadap perjanjian yang disepakati oleh presiden sebelumnya tanpa adanya persetujuan Kongres. Hal ini kemudian mendorong pengambilan keputusan AS keluar dari perjanjian JCPOA yang dilakukan melalui tingkat keputusan presidensial yaitu presidential memoranda. Berdasarkan hal-hal tersebut, penulis menilai bahwa faktor individual adalah faktor yang paling dominan dalam mempengaruhi proses pembuatan kebijakan luar negeri AS terkait perjanjian JCPOA.

Setelah mempertimbangkan faktor-faktor masukan diatas melalui proses pengambilan keputusan yang mengacu pada procedural rationality, Amerika Serikat mengidentifikasi beberapa permasalahan dalam perjanjian JCPOA yaitu perjanjian tersebut tidak mengakomodasi pembatasan program rudal balistik Iran, akses pemeriksaan oleh IAEA yang masih terbatas, dan pembatasan program pengayaan nuklir Iran yang tidak permanen. Perbaikan atas tiga permasalahan tersebut menjadi keharusan yang ditetapkan sebagai tujuan Amerika Serikat untuk tetap berada dalam perjanjian JCPOA. Hal ini dikarenakan tujuan utama Amerika Serikat terhadap Iran adalah mencegah segala kemungkinan Iran memiliki senjata nuklir.

Dalam mencapai tujuan tersebut, Amerika Serikat memiliki dua pilihan kebijakan yaitu mempertahankan perjanjian JCPOA dengan berupaya menegosiasikan perjanjian tambahan yang mengakomodasi penyelesaian tiga masalah yang telah disebutkan dalam paragraf sebelumnya. Dan pilihan kebijakan yang kedua adalah keluar dari perjanjian JCPOA sekaligus mengembalikan sanksi ekonomi terhadap Iran. Pada awalnya Amerika Serikat memilih untuk bertahan dan mengupayakan pembuatan perjanjian tambahan karena dianggap lebih bisa mencapai tujuannya yaitu mencegah Iran memiliki senjata nuklir. Upaya pembuatan perjanjian tambahan dilakukan Amerika Serikat dengan bernegosiasi dengan sekutunya dari Eropa yaitu Perancis, Jerman dan Inggris. Namun karena upaya negosiasi pembuatan perjanjian tambahan tidak tercapai, Amerika Serikat pada akhirnya memutuskan keluar dari perjanjian nuklir Joint Comprehensive Plan of Action (JCPOA). Dengan kata lain, keputusan Amerika Serikat keluar dari perjanjian JCPOA bukanlah pilihan kebijakan dengan prospek keberhasilan yang paling baik untuk mencapai tujuannya mencegah Iran memiliki senjata nuklir melainkan sebagai pilihan kebijakan terakhir.

Berkaca dari alasan yang melatarbelakangi keputusan AS keluar dari perjanjian JCPOA di tahun 2015, pemerintahan Joe Biden tentu menghadapi tantangan serupa mulai di level internasional hingga level domestik. Seperti yang sudah dijelaskan sebelumnya bahwa kepercayaan Iran kepada AS telah jatuh apalagi dengan terjadinya ketegangan militer antar keduanya belakangan ini. Hal ini membuat AS cenderung sulit untuk mengajak Iran duduk bersama di meja perundingan. Dari level domestik, Senat AS saat ini pun mayoritas kursi masih didominasi oleh Partai Republik yang berhaluan keras terhadap Iran. Oleh karena itu, menarik untuk ditunggu kebijakan apa yang akan diambil Biden terkait nuklir Iran.

\section{DAFTAR PUSTAKA}

Aljazeera. (2018, May 9). World leaders react to US withdrawal from Iranian nuclear deal. Retrieved from aljazeera.com: https://www.aljazeera.com/news/2018/5/9/world-leadersreact-to-us-withdrawal-from-iranian-nuclear-deal

Arms Control Association. (2018, April 25). The P5+1 and Iran Nuclear Deal Alert,. Retrieved from armscontrol.org: https://www.armscontrol.org/blog/2018-04-25/p51-irannuclear-deal-alert-april-25-2018 
Beauchamp, Z. (2018, May 8). Trump's withdrawal from the Iran nuclear deal, explained. Retrieved from Vox.com: https://www.vox.com/world/2018/5/8/17328520/iran-nucleardeal-trump-withdraw

Biden, J. (2020, September 13). There's a smarter way to be tough on Iran. Retrieved from CNN Political Op-Eds: https://edition.cnn.com/2020/09/13/opinions/smarter-way-tobe-tough-on-iran-joe-biden/index.html

Blackwill, R. D., \& Gordon, P. H. (2016, November). Repairing the U.S. - Israel Relation. Retrieved from Council on Foreign Relations: https://cdn.cfr.org/sites/default/files/pdf/2016/11/CSR76_BlackwillGordon_Isr ael.pdf

Blanton, S. L., \& Kegley, C. W. (2011). World Politics Trend and Transformation. Boston: Cengage.

Borger, J. (2018, April 1). Iran Nuclear Deal Talks Persist As Trump Looks Poised To Kill It. Retrieved from The Guardian: https://www.theguardian.com/world/2018/mar/31/iran-deal-donald-trump-johnbolton-mike-pompeo

Borger, J., \& Smith, D. (2018, April 24). Macron Pitches New Iran Deal to Sweeten Existing Agreement for Trump. Retrieved from The Guardian:

https://www.theguardian.com/world/2018/apr/24/trump-iran-deal-macron-newagreement-white-house-visit

Brook, T. V., \& Korte, G. (2018, March 22). Trump Removes, HR McMaster National Security Adviser Replacing Him John Bolton. Retrieved from usatoday.com: https://www.usatoday.com/story/news/politics/2018/03/22/trump-removes-h-rmcmaster-national-security-adviser-replacing-him-john-bolton/425301002/

Bustelo, P. (1998). The East Asian Financial Crises: an Analytical Survey. Madrid: ICEI.

Cavalli, C. D. (2013). The Basics of American Government. Georgia: University Press of North Georgia.

CBS News. (2018, January 23). Tillerson Finds Skeptics As He Presses EU Allies On Iran Deal. Retrieved from cbsnews.com: https://www.cbsnews.com/news/rex-tillersondonald-trump-iran-nuclear-deal-skepticism-in-europe-france/

Chang, A. (2015, August 6). Lobbyists Spending Millions To Sway The Undecided On Iran Deal. Retrieved from npr.org: https://www.npr.org/sections/itsallpolitics/2015/08/06/429911872/in-iran-dealfight-lobbyists-are-spending-millions-to-sway-12-senators

Chotiner, I. (2018, May). Unraveling the Iran nuclear agreement could destabilize the Middle East in new. Retrieved from Slate.com: https://slate.com/news-andpolitics/2018/05/what-the-end-of-theiran-

Chu, Y.-W. (2016). The Asian Developmental State. New York: Palgrave Macmillan.

CIA. (2017, October 12). Director Pompeo Delivers Remarks at UT Austin National Security Forum. Retrieved from cia.gov: https://www.cia.gov/news-information/speechestestimony/2017-speeches-testimony/pompeo-delivers-remarks-at-ut-austinnational-security-forum.html

Cordesman, A. H. (2018, March 28). U.S. National Security Strategy in the MENA Region. Retrieved from JSTOR: https://www.jstor.org/stable/resrep22440

Cornberg, T. (2017). No EU, no Iran deal: the EU's choice between multilateralism and the transatlantic link. The Nonproliferation Review Vol. 24 Issue 3-4, 243-259.

Crowley, M., \& Johnson, E. (2018, January 3). Iran Protests Could Move Trump To Kill Nuclear Deal. Retrieved from politico.eu: https://www.politico.eu/article/iran-protestscould-move-trump-to-kill-nuclear-deal/ 
CSIS Missile Defense Project. (2020, July 16). Missiles of Iran. Retrieved from missilethreat.csis.org: https://missilethreat.csis.org/country/iran/

Davenport, K. (2021, March). The Joint Comprehensive Plan of Action (JCPOA) at a Glance. Retrieved from Arms Control Association: https://www.armscontrol.org/factsheets/JCPOA-at-a-glance

DiChristoper, T. (2017, October 13). Trump Says US Will Terminate Iran Nuclear Deal If He Can't Reach Solution With Congress, Allies. Retrieved from CNBC:

https://www.cnbc.com/2017/10/13/trump-says-us-will-leave-iran-nuclear-deal-ifhe-cant-reach-solution-with-congress-allies.html

Dixit, A. (2018, March 5). Iran is Implementing Nuclear-related JCPOA Commitments, Director General Amano Tells LAEA Board. Retrieved from iaea.org: https://www.iaea.org/newscenter/news/iran-is-implementing-nuclear-relatedjcpoa-commitments-director-general-amano-tells-iaea-board

DW. (2017, September 20). What Are Donald Trump's Objections To The Iran Nuclear Deal? Retrieved from DW: https://www.dw.com/en/what-are-donald-trumpsobjections-to-the-iran-nuclear-deal/a-40601669

Echagüe, A. (2015). The United States: redefining engagement? . In K. K. (Ed.), Geopolitics and Democracy in the Middle East (pp. 181-194). Madrid: Fride.

Eisendstadt, M., \& Pollock, D. (2012, November 7). Friends with Benefits: Why the U.S.-Israeli Alliance Is Good for America. Retrieved from Washington Institute: https://www.washingtoninstitute.org/policy-analysis/friends-benefits-why-usisraeli-alliance-good-america

Ellyatt, H. (2018, March 30). Iran Nuclear Deal Won't Outlast Trump's First Term'In Office. Retrieved from CNBC: https://www.cnbc.com/2018/03/30/iran-nuclear-dealwont-outlast-trumps-first-term-in-office.html

European External Action Sevice. (2018, May 8). The Joint Comprehensive Plan of Action $(J C P O A)$ and its implementation. Retrieved from eeas.europa.eu: https://eeas.europa.eu/headquarters/headquartershomepage_en/32286/Nuclear\%20Agreement

Federation of American Scientists. (2018, May 8). NSPM 11: Ceasing United States Participation in the Joint Comprehensive Plan of Action. Retrieved from fas.org: https:// fas.org/irp/offdocs/nspm/nspm-11.pdf

Friedman, E. (1996). Intervention of the Proper Kind. The Review of Politics, Vol. 58, No. 2 (Spring, 1996), 413-417.

Gaouette, N. (2017, September 20). Iran's Roubani Pushes Back On Trump. Retrieved from CNN: https://edition.cnn.com/2017/09/20/politics/iran-rouhani-trumpnuclear/index.html

Gatten, E. (2018, April 19). UK, France And Germany In Intense' Talks With US To Address Iran Deal Concerns. Retrieved from The Telegraph: https://www.telegraph.co.uk/news/2018/04/19/uk-france-germany-intense-talksus-address-iran-deal-concerns/

Gladstone, R. (2017, October 5). What Is the Iran Nuclear Deal? And Why Does Trump Hate It? Retrieved from The New York Times: https://www.nytimes.com/2017/10/05/world/middleeast/iran-nuclear-deal.html

Global Fire Power. (2018, May). Defense Spending by Country. Retrieved from globalfierpower.com: https://www.globalfirepower.com/defensespendingHaggard, S. (2018). Developmental States. New York: Cambridge University Press. 
Hennigan, W. J., Bennett, B., \& Wilkinson, T. (2017, October 4). Trump's National Security Aides Voice Support For The Iran Nuclear Deal. Retrieved from LA Times: https://www.latimes.com/nation/la-fg-trump-iran-20171003-story.html

Ho, C. (2015, Juli 17). Jewish American Groups Prepare To Spend Millions To Lobby On Iran Deal. Retrieved from Washington Post: https://www.washingtonpost.com/news/powerpost/wp/2015/07/17/jewishamerican-groups-prepare-to-spend-millions-to-lobby-on-irandeal/?utm_term $=.2 \mathrm{c} 7 \mathrm{~d} 7 \mathrm{~d} 5 \mathrm{ad} 8 \mathrm{f} 8$

Ho, C. (2015, August 13). Mega-Donors Opposing Iran Deal Have Upper Hand In Fierce Lobbying Battle. Retrieved from Washington Post:

https://www.washingtonpost.com/news/powerpost/wp/2015/08/13/megadonors-opposing-iran-deal-have-upper-hand-in-fierce-lobbyingbattle/?utm_term $=.23382 \mathrm{a} 2162 \mathrm{ba}$

Holpuch, A. (2018, May 8). Donald Trump Says US Will No Longer Abide By Iran Deal - As It Happened. Retrieved from theguardian.com: https://www.theguardian.com/world/live/2018/may/08/iran-nuclear-dealdonald-trump-latest-live-updates

Holsti, K. J. (1983). International Politics: A Framework for Anlysis 4th Edition. London: Prentice.

Hundt, D., \& Uttam, J. (2017). Varieties of Capitalism in East Asia. London: Palgrave Macmillan.

Immenkamp, B. (2018, May). Future of the Iran Nuclear Deal: How Much Can US Pressure Isolate Iran. Retrieved from euro parliament: https://www.europarl.europa.eu/RegData/etudes/BRIE/2018/621897/EPRS_B RI

ISN Security Watch. (2017, August 14). Is Trump Gearing Up To End The Iran Nuclear Deal? Retrieved from oilprice.com: https://oilprice.com/Geopolitics/International/IsTrump-Gearing-Up-To-End-The-Iran-Nuclear-Deal.html

Jett, D. C. (2018). The Iran Nuclear Deal: Bombs, Bureaucrats, and Billionaires. Cham, Switzerland: Springer.

Johnson, T. (2013, January 24). Congress and U.S. Foreign Policy. Retrieved from cfr.org: http://www.crf-usa.org/war-in-iraq/foreign-policy.html

Katzman, K. (2021, April 6). Congressional Research Service: Iran Sanctions. Retrieved May 1, 2021, from FAS |Federation of American Scientists: https:// fas.org/sgp/crs/mideast/RS20871.pdf

Kaul, I., Grunberg, I., \& Stern, M. (1999). Global Public Goods: International Cooperation in the 21st Century. Oxford: Oxford University Press.

Kegley, C. W., \& Raymond, G. A. (2009). The Global Future: A Brief Introduction to World Politics 3rd Edition. Boston: Wadsworth Publishing.

Khoiriati, S. D. (2013). Indofood Indonesia: Dari Konglomerasi ke Transformasi. In M. Mas'oed, R. N. Arfani, M. Hapsari, P. S. Winanti, \& S. D. Khoiriati, Adidaya Ekonomi Dari Selatan: Kemunculan dan Transformasi Perusahaan Multinasional Negara Sedang Berkembang (pp. 171-203). Yogyakarta: Institute of International Studies (IIS).

Kollman, K. (2015). The American Political System 2nd Edition. New York: W. W. Norton \& Company.

Kruzel, J. (2018, May 3). What You Need To Know Ahead Of Donald Trump's Iran Deal Deadline. Retrieved from politifact.com: https://www.politifact.com/truth-Ometer/article/2018/may/03/what-you-need-know-ahead-donald-trumps-iran-deald/ 
Kumagai, S. (2008). Journey Through the Secret History of the Flying Geese Model. Chiba: IDEJETRO.

Labott, E., \& Cohen, Z. (2017, October 5). Tillerson's Dramatic Plan To Save Iran Deal, Keep

Up Pressure. Retrieved from CNN:

https://edition.cnn.com/2017/10/03/politics/trump-tillerson-iran-dealplan/index.html

Labott, E., Walsh, D., \& Serfaty, S. (2015, August 3). Washington Battle Rages Over Iran Nuclear Deal's Fate. Retrieved from CNN:

https://edition.cnn.com/2015/08/03/politics/aipac-iran-nuclear-dealcongress/index.html

Liptak, K., Cohen, Z., \& Labott, E. (2017, October 6). President Trump Plans To 'Decertify' Iran Nuclear Deal Next Week. Retrieved from CNN: https://edition.cnn.com/2017/10/05/politics/trump-iran-deal-deadlineplan/index.html

Manning, J. E. (2016, December 5). Membership of the 114th Congress: A Profile. Retrieved from fas.org: https:// fas.org/sgp/crs/misc/R43869.pdf

Manning, J. E. (2018, December 20). Membership of the 115th Congress: A Profile. Retrieved from fas.org: https:// fas.org/sgp/crs/misc/R44762.pdf

Mas'oed, M. (1990). Ilmu Hubungan Internasional: Disiplin dan Metodologi. Yogyakarta: LP3ES.

McCarthy, N. (2018, June 8). Where U.S. Troops Are Based In The Middle East. Retrieved from statiste.com: https://www.statista.com/chart/9727/where-us-troops-are-based-inthe-middle-east/

McKenzie, S. (2018, April 12). Pompeo Uses Meeting With Saudis As An Opportunity To Slam The Iran Nuclear Deal. Retrieved from CNN:

https:/ / edition.cnn.com/2018/04/29/politics/pompeo-iran-nuclear-dealintl/index.html

Middle East Monitor. (2017, January 26). Iran official, pro-Tehran lobbyist hosted by Obama's White House 33 times. Retrieved from middleeastmonitor.com:

https://www.middleeastmonitor.com/20170126-iran-official-pro-tehran-lobbyisthosted-by-obamas-white-house-33-times/

Mohammed, A., \& Irish, J. (2018, April 13). Progress In Iran Deal Talks, But Trump Stance Uncertain. Retrieved from Reuters: https://www.reuters.com/article/us-irannuclear-diplomat/progress-in-iran-deal-talks-but-trump-stance-uncertainidUSKBN1HJ38G

Morello, C. (2018, March 28). John Kerry warns against leaving the Iran deal. Retrieved from washingtonpost.com: https://www.washingtonpost.com/world/nationalsecurity/john-kerry-warns-against-leaving-the-iran-deal/2018/03/27/76811f7ba6bd-4725-910f-4eaa58db686b_story.html

Mulligan, S. P. (2018, May 4). Withdrawal From International Agreements-Legal Framework, The Paris Agreement, And The Iran Nuclear Agreement. Retrieved from fas.org: https:// fas.org/sgp/crs/row/R44761.pdf

Mulligan, S. P. (2018, May 17). Withdrawal from the Iran Nuclear Deal: Legal Authorities and Implications. Retrieved from fas.org: https://fas.org/sgp/crs/nuke/LSB10134.pdf

NIAC. (2018). About Niac. Retrieved from niaccouncil.org: https://www.niacouncil.org/about-niac/

Padeanu, I. E. (2016, December 1). Is the Trump Administration Bound by the Iran Deal. Retrieved from Yale Edu: https://www.yjil.yale.edu/is-the-trump-administrationbound-by-the-iran-deal/ 
Palmer, A., \& Parti, T. (2018, October 8). Iran Deal Launches Lobbying War. Retrieved from politico.com: https://www.politico.com/story/2015/07/iran-deal-launcheslobbying-war-120121

Pecanha, S., \& Collins, K. (2018, February 7). Only 5 Nations Can Hit Any Place on Earth With a Missile. Retrieved from nytimes.com: https://www.nytimes.com/interactive/2018/02/07/world/asia/northkorea-

Peters, B. G., \& Pierre, J. (1998). Governance Without Government? Rethinking Public Administration. Journal of Public Administration Research and Theory: J-PART, Vol. 8, No. 2, 223-243.

Rafio Free Europe Radio Liberty. (2018, September 26). Global Nuclear Stockpiles. Retrieved from rferl.org: https://www.rferl.org/a/global-nuke-stockpile/28593554.html

Rasheed, A. (2020, January 3). Iran's Soleimani and Iraq's Mubandis killed in US air strike: Militia spokesman. Retrieved from The Jakarta Post: https://www.thejakartapost.com/news/2020/01/03/irans-soleimani-and-iraqsmuhandis-killed-in-u-air-strike-militia-spokesman.html

Rosati, J. A., \& Scot, J. M. (2011). The Politics of the United States Foreign Policy 5th Ed. Boston: Wadsworth.

Rosenau, J. N., Boyd, G., \& Thompson, K. W. (1976). World Politics: An Introduction. New York: The Free Press.

Rosenberg, M. J. (2015, September 11). AIP AC Spent Millions of Dollars to Defeat the Iran Deal. Instead, It May Have Destroyed Itself. Retrieved from thenation.com: https://www.thenation.com/article/archive/aipac-spent-millions-of-dollars-todefeat-the-iran-deal-instead-it-may-have-destroyed-itself/

Sanger, D. E. (2017, Februari 3). U.S. Imposes New Sanctions on Iran Over Missile Test. Retrieved from The New York Times: https://www.nytimes.com/2017/02/03/us/politics/iran-sanctions-trump.html

Sato, Y. (2019). Reemerging Developmental State in Democratize Indonesia. In Y. Takagi, V. Kanchoochat, \& T. Sonobe, Developmental State Building: The Politics of Emerging Economies (pp. 69-95). Singapore: Springer Nature SIngapore.

Sparks, G. (2018, May 9). Majority say US Should Not Withdraw from Iran Nuclear Agreement. Retrieved from CNN: https://edition.cnn.com/2018/05/08/politics/poll-iranagreement/index.html

SSRS. (2018, May 8). Polling on Iran and JCPOA. Retrieved from CNN: http://cdn.cnn.com/cnn/2018/images/05/07/rel5c.-.iran.pdf

Tanter, R. (2017, October 13). Hawks Top Doves In Political War Over Iran Deal. Retrieved from The Hill: https://thehill.com/opinion/national-security/355344-hawks-topdoves-in-political-war-over-iran-deal

The Aspen Institute. (2017, July 20). ASPEN Security Forum 2017. Retrieved from aspensecurityforum.org: http:/ / aspensecurityforum.org/wpcontent/uploads/2017/07/The-View-from-Langley.pdf

The Harvard Gazette. (2018, May 8). Assessing the Iran Deal Pullout. Retrieved from Harvard.edu: https://news.harvard.edu/gazette/story/2018/05/harvard-analystsassessthe-

The New York Times. (2018, May 8). Trump Withdrew From the Iran Deal. Here's How Republicans,Democrats and the World Reacted. Retrieved from nytimes.com: https://www.nytimes.com/2018/05/08/world/middleeast/trump-iran-dealrepublicans-democrats-world-reactions.html 
The White House. (2017, October 13). Remarks by President Trump on Iran Strategy. Retrieved from whitehouse.gov: https://www.whitehouse.gov/briefings-statements/remarkspresident-trump-iran-strategy/

The White House. (2017, September 19). Remarks by President Trump to the 72nd Session of the United Nations General Assembly. Retrieved from whitehouse.gov: https://www.whitehouse.gov/briefings-statements/remarks-president-trump72nd-session-united-nations-general-assembly/

The White House. (2018, January 30). President Donald J. Trump's Foreign Policy Puts America First. Retrieved from whitehouse.gov: https://www.whitehouse.gov/briefingsstatements/president-donald-j-trumps-foreign-policy-puts-america-first/

The White House. (2018, May 8). Press Briefing By National Security Advisor John Bolton on Iran. Retrieved from whitehouse.gov: https://www.whitehouse.gov/briefingsstatements/press-briefing-national-security-advisor-john-bolton-iran/

The White House. (2018, May 8). Remarks by President Trump on the Joint Comprehensive Plan of Action. Retrieved from whitehouse.gov: https://www.whitehouse.gov/briefingsstatements/remarks-president-trump-joint-comprehensive-plan-action/

The White House. (2018, January 12). Statement by the President on the Iran Nuclear Deal. Retrieved from whitehouse.gov: https://www.whitehouse.gov/briefingsstatements/statement-president-iran-nuclear-deal/

The White House. (2018, May 9). WTAS: Support For President Donald J. Trump's Decision To End United States Participation In The Iran Deal. Retrieved from whitehouse.gov: https://www.whitehouse.gov/briefings-statements-wtas-support-president-donaldj-trumps-decision-end-united-states-participation-iran-deal/

The White House. (2021, February 19). Remarks by President Biden at the 2021 Virtual Munich Security Conference. Retrieved from Whitehouse.gov: https://www.whitehouse.gov/briefing-room/speechesremarks/2021/02/19/remarks-by-president-biden-at-the-2021-virtual-munichsecurity-conference/

The White House of President Barrack Obama. (2015, October 19). Presidential Memoranda - Adoption Day for the Joint Comprehensive Plan of Action. Retrieved from obamawhitehouse.archives.gov: https://obamawhitehouse.archives.gov/the-pressoffice/2015/10/19/presidential-memoranda-adoption-day-joint-comprehensiveplan-action

Toosi, N. (2018, June 27). Iranian-Americans Set Up Lobbying Arm To Counter Pro-Israel Groups. Retrieved from politico.com: https://www.politico.com/story/2015/06/iraniansamerican-pac-niac-counter-pro-israel-lobby-119483

Torbati, Y. (2016, November 9). Trump Election Puts Iran Nuclear Deal On Shaky Ground. Retrieved from Reuters: https://www.reuters.com/article/us-usa-election-trumpiran/trump-election-puts-iran-nuclear-deal-on-shaky-ground-idUSKBN13427E

Vakil, S., \& Quilliam, N. (2019, 10 22). Chatamhouse. Retrieved May 21, 2021, from Research Paper: Getting to a New Iran Deal: https://www.chathamhouse.org/sites/default/files/2019-10-22GettingToANewIranDeal.pdf

Vick, K. (2018, May 3). To Nix or to Fix: Trump's Major Dilemma on the Iran Deal. Retrieved from time.com: https://time.com/5264150/trumps-major-dilemma-on-the-irandeal/

Vine, D. (2015, June). Where in the World Is the U.S. Military? Retrieved from politico.com: https://www.politico.com/magazine/story/2015/06/us-military-bases-aroundthe-world-119321 
Wallace, W. (1971). Foreign Policy And The Political Process. London: The Macmillan Press.

Wilkinson, T., \& Bierman, N. (2018, April 27). Merkel follows Macron to Washington in hopes of bolding Trump to Iran nuclear deal. Retrieved from LA Times:

https://www.latimes.com/politics/la-na-pol-trump-merkel-20180427-story.html

Williamson, J. (1990). What Washington Means by Policy Reform. In J. Williamson, Latin American Adjustment: How Much Has Happened? (pp. 5-36). Washington: Institute for International Economics.

Wilner, M. (2017, October 9). AIP AC Partners To Redefine Debate On Iran Agreement. Retrieved from The Jerusalem Post: https://www.jpost.com/AmericanPolitics/With-White-House-allies-AIPAC-works-to-reshape-Iran-deal-debate507069

Winanti, P. S. (2003). Developmental State dan Tantangan Globalisasi: Pengalaman Korea Selatan. Jurnal Ilmu Sosial dan Ilmu Politik. Volume 7 Nomer 2, 175-204.

Winter, J., Gramer, R., \& Luce, D. D. (2017, July 21). Trump Assigns White House Team to Target Iran Nuclear Deal Sidelining State Department. Retrieved from foreignpolicy.com: https:/ foreignpolicy.com/2017/07/21/trump-assigns-white-house-team-totarget-iran-nuclear-deal-sidelining-state-department/

Woodruff, B., \& Ackerman, S. (2018, January 10). McMaster Rushes to Save the Iran Deal That Trump Promised to Kill. Retrieved from thedailybeast.com: https://www.thedailybeast.com/mcmaster-rushes-to-save-the-iran-nuke-deal

Worl Bank. (2017). Total GDP of Countries. Retrieved from https://wits.worldbank.org

World Bank. (2017). Countries GDP Growth. Retrieved from worldbank.org: https://wits.worldbank.org

World Bank. (2017). United States, France, German, China, Russia, United Kingdom, and Iran Exports Imports to MEN A Region. Retrieved from worldbank.org: https://wits.worldbank.org/

Younes, A. (2018, May 1). What's behind the push against Iran nuclear deal?,. Retrieved from AlJazeera: https://www.aljazeera.com/news/2018/04/fixation-iranian-nuclearthreat-180426085605834.html 